Department of Pharmacodynamics and Biopharmacy

Faculty of Pharmacy

University of Szeged

Supervisor: Róbert Gáspár Ph.D.

\title{
Sexual hormone effects \\ of honeybee (Apis mellifera) drone milk \\ in male and female rats
}

Ph.D. Thesis

by

Adrienn Seres Pharm.D.

Szeged

2014 


\section{Contents}

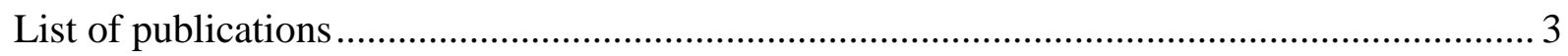

1. Publications related to the Ph.D. thesis ........................................................................ 3

2. Presentations related to the Ph.D. thesis ........................................................................ 4

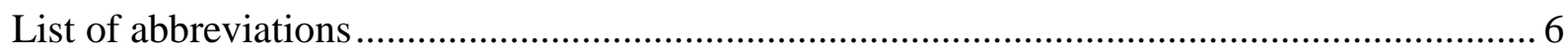

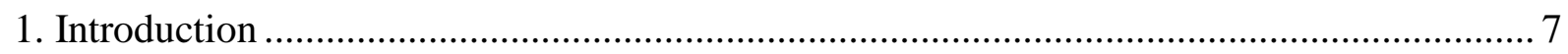

1.1. Natural compounds with hormonal effect ....................................................... 7

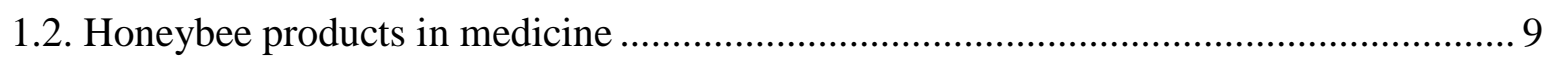

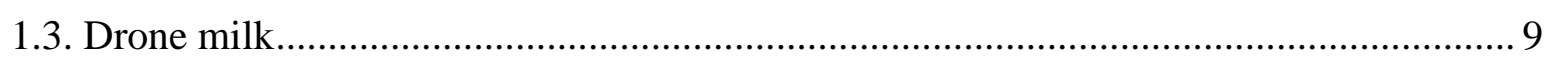

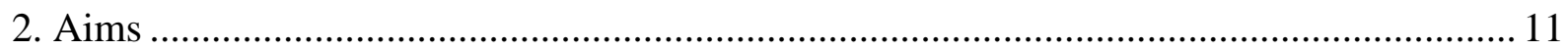

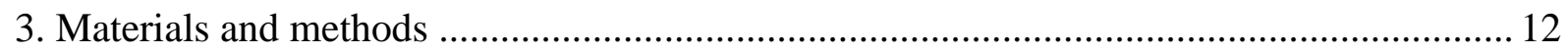

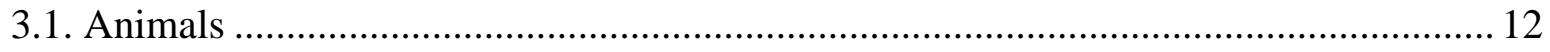

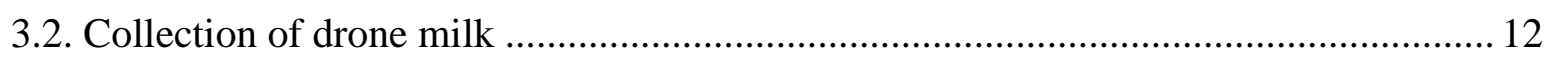

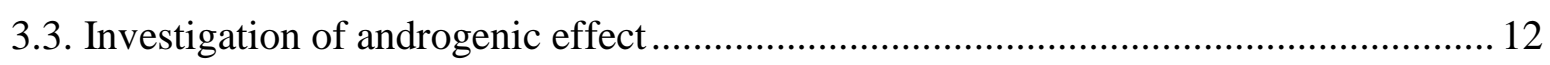

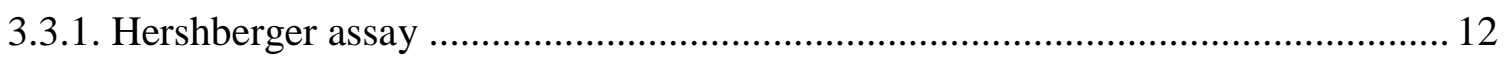

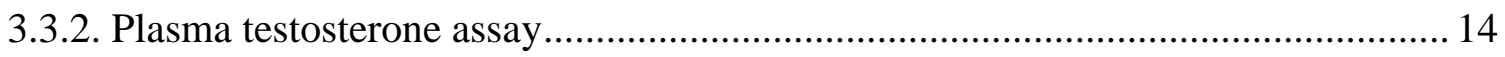

3.3.3. Determination of prostatic Slap mRNA by real-time RT-PCR ............................. 14

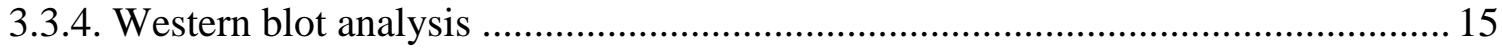

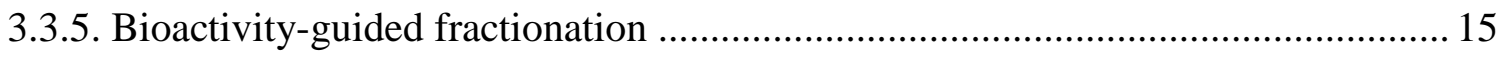

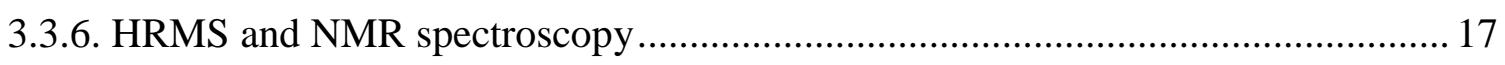

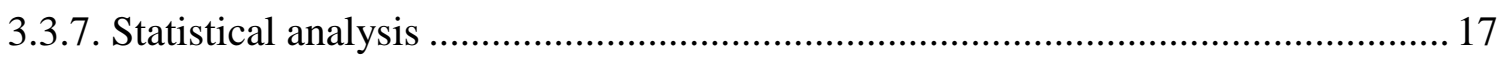

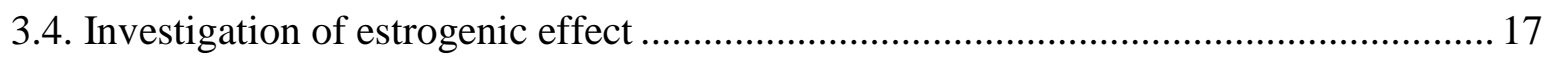

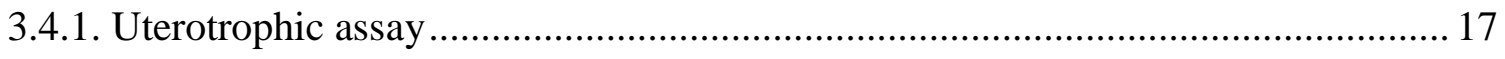

3.4.2. Determination of C3 mRNA by real-time RT-PCR .......................................... 18

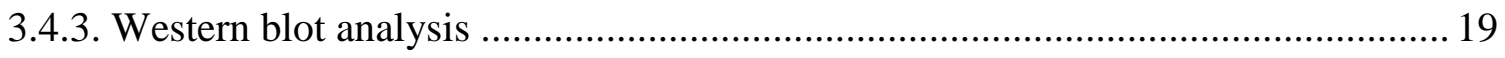

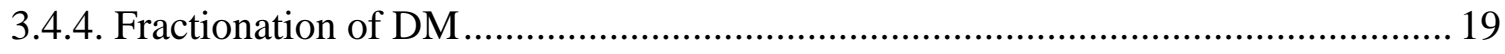

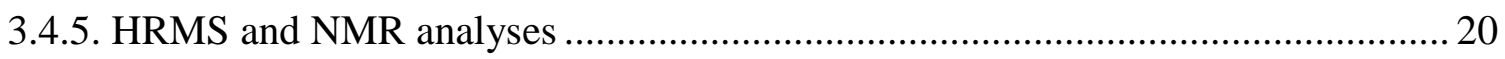

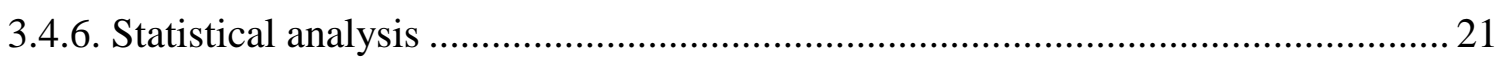

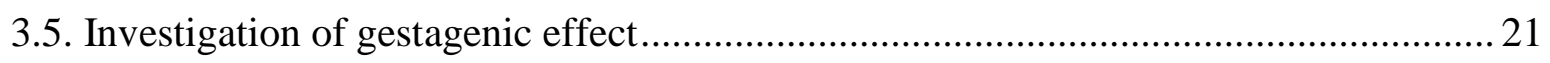

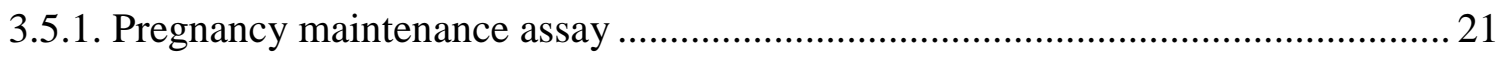

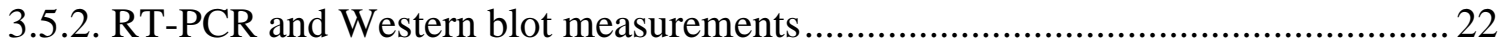




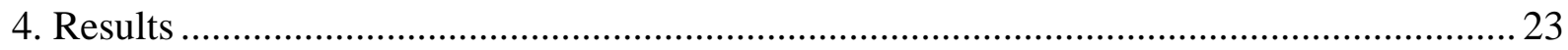

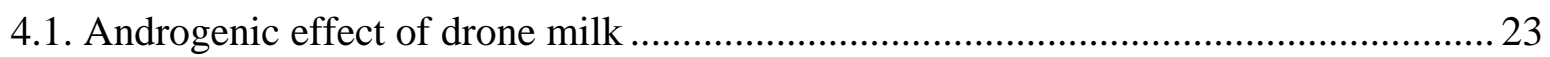

4.1.1. In vivo androgenic effect of crude drone milk ................................................... 23

4.1.2. Measurement of plasma testosterone level............................................................ 24

4.1.3. Measurements of prostatic Slap mRNA and protein........................................... 25

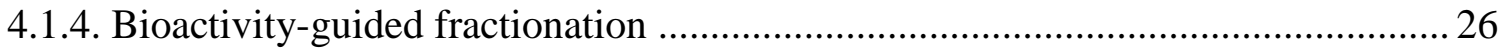

4.1.5. Identification of the androgenic compound(s) of raw drone milk ....................... 28

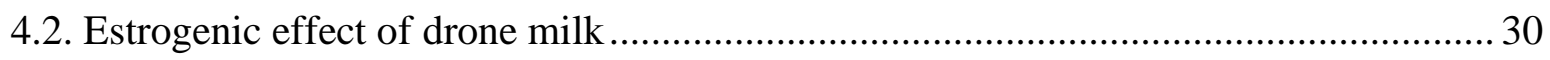

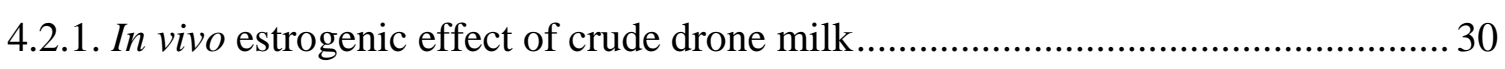

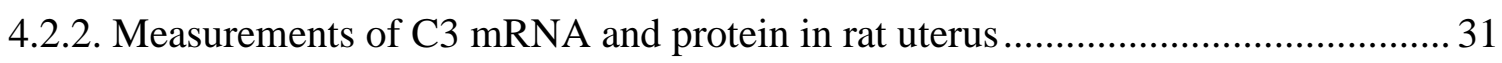

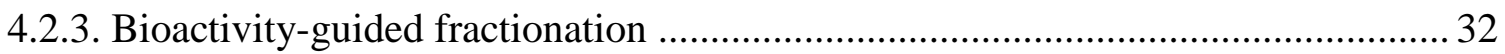

4.2.4. Identification of the estrogenic compound(s) of raw drone milk .......................... 33

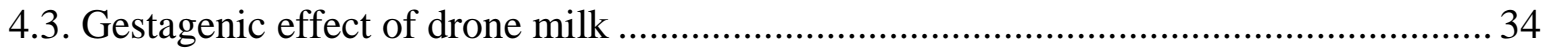

4.3.1. In vivo gestagenic effect of crude drone milk .................................................. 34

4.3.2. Measurements of CRLR mRNA and protein in rat uterus .................................... 35

4.3.3. Measurement of the gestagenic efficacy of drone milk ...................................... 35

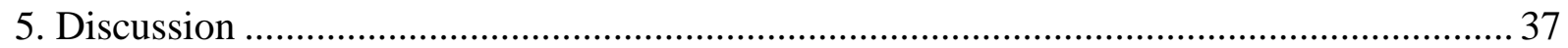

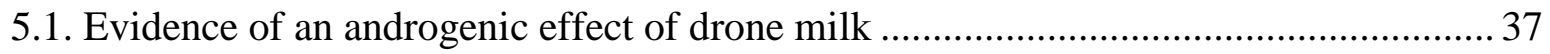

5.2. Evidence of an estrogenic effect of drone milk.......................................................... 39

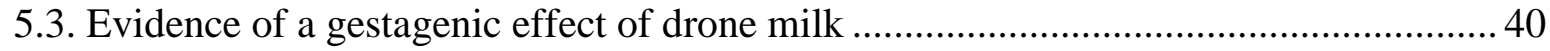

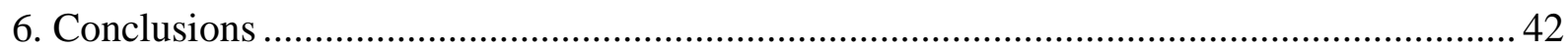

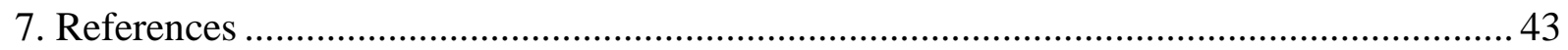

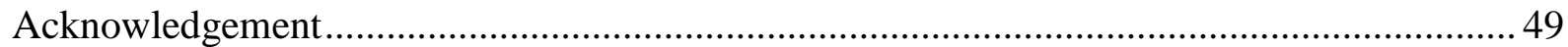




\section{List of publications}

\section{Publications related to the Ph.D. thesis}

I Seres AB, Ducza E, Bathori M, Hunyadi A, Beni Z, Dekany M, Gaspar R: Raw drone milk of honeybee elicits uterotrophic effect in rat: evidence for estrogenic activity

Journal of Medicinal Food 16:(5) pp. 404-409. (2013)

IF $: 1.642$

II Seres Adrienn: A heretej ösztrogénhatásának vizsgálata patkányban

„Együtt a biztosabb tudományos karrierért, a jövőtervezésért” VII. Ph.D. Conference, Budapest, Hungary

Professzorok az Európai Magyarországért Egyesület, pp. 348-355. (2013)

III Seres AB, Ducza E, Báthori M, Hunyadi A, Béni Z, Dékány M, Hajagos-Tóth J, Verli J, Gáspár R: Androgenic effect of honeybee drone milk in castrated rats: roles of methyl palmitate and methyl oleate

Journal of Ethnopharmacology 153:(2) pp. 446-453. (2014) IF: 2.755

IV Seres Adrienn, Ducza Eszter, Gáspár Róbert: Investigation of gestagenic effect of raw drone milk in rats

Acta Pharmaceutica Hungarica 84:(043) pp. 77-82. (2014) 


\section{Presentations related to the Ph.D. thesis}

I Seres Adrienn: Heretej androgén hatásának vizsgálata hím patkányokon in vivo Scientific Students' Associations Conference (TDK), Szeged, Hungary, 2009 (Oral presentation)

II Seres Adrienn: Heretej androgén hatásának vizsgálata hím patkányokon in vivo National Scientific Students’ Associations Conference (OTDK), Pécs, Hungary, 2009 (Oral presentation)

III Seres Adrienn, Gáspár Róbert: Ösztrogén és androgén moduláló hatások vizsgálata heretejjel patkányokban in vivo

XIV. Congressus Pharmaceuticus Hungaricus, Budapest, Hungary, 2009 (Poster)

IV Seres Adrienn, Gáspár Róbert: A heretej androgén moduláló hatásának vizsgálata patkányokon in vivo

Common Scientific Conference of Hungarian Physiological Society (MÉT) and Hungarian Society for Experimental and Clinical Pharmacology (MFT), Szeged, Hungary, 2010 (Poster)

V Adrienn Seres, Eszter Ducza, Róbert Gáspár: Sexual hormone-like effect of raw drone milk in female rats

Pharmaceutical Sciences for the Future of Medicines 3rd PharmSciFair Meeting, Prague, Czech Republic, 2011 (Poster)

VI Seres AB, Ducza E and Gáspár R: Estrogenic and gestagenic effect of raw drone milk Diczfalusy Symposium on reproductive health, Szeged, Hungary, 2011 (Poster)

VII Adrienn Seres, Eszter Ducza, Róbert Gáspár: Sexual hormone-like effect of raw drone milk in female rats

„Molekulától a gyógyszerig” TÁMOP Conference, Szeged, Hungary, 2012 (Poster) 
VIII Seres Adrienn: A heretej ösztrogén hatásának vizsgálata patkányban XX. Szent-Györgyi Napok, Szeged, Hungary, 2013 (Oral presentation)

IX Seres AB, Ducza E, Báthori M, Hunyadi A, Béni Z, Dékány, Hajagos Tóth J, Verli J, Gáspár R: Androgenic effect of honeybee drone milk in castrated rats

Bridges in Life Sciences 9th Annual Scientific Conference, Split, Croatia, 2014 (Poster and oral presentation) 


\section{List of abbreviations}

C: $\quad$ combination of methyl oleate and methyl palmitate

C3: $\quad$ complement component 3

CC: $\quad$ column chromatography

CID: $\quad$ collision-induced dissociation

CRLR: calcitonin receptor-like receptor

CT: threshold cycle

DHEA: dehydroepiandrosterone

DM: drone milk

$\mathrm{E}_{2}$ : $\quad 17 \beta$-estradiol valerate

ED: erectile dysfunction

ER: $\quad$ estrogen receptor

F: $\quad$ flutamide

GC-HRMS: gas chromatography-high-resolution mass spectrometry

HR-ESI-MS: high-resolution electrospray ionization-mass spectrometry

HSD: hydroxysteroid dehydrogenase

ICI: $\quad$ ICI 182.780

$\mathrm{MeOH}$ : methanol

MM: $\quad$ mucilage methylcellulose

MO: methyl oleate

MP: methyl palmitate

NMR: nuclear magnetic resonance spectroscopy

P: $\quad$ progesterone

RJ: $\quad$ royal jelly

RPCC: $\quad$ reversed-phase column chromatography

RQ: $\quad$ relative quantity

RT-PCR: reverse transcription polymerase chain reaction

SEM: $\quad$ standard error of the mean

SLAP: $\quad$ Spot14-like androgen-inducible protein

SP: $\quad$ spironolactone

$\mathrm{T}$ : testosterone

TLC: thin-layer chromatography 


\section{Introduction}

\subsection{Natural compounds with hormonal effect}

Phytoestrogens are plant derivatives with estrogen-like effects that are able to bind to human estrogen receptors (ER). Phytoestrogens are found in high amounts for example in soybeans, so the effects of soy isoflavonoids (daidzein, genistein and glycitein) have been extensively studied in recent years. These soy isoflavonoids (Fig. 1) can be alternatives to conventional hormone therapy in postmenopausal women (Aso, 2010; Messina, 2014), because they bind to the human estrogen receptors, despite their non-steroidal structures (Vitale et al., 2013).
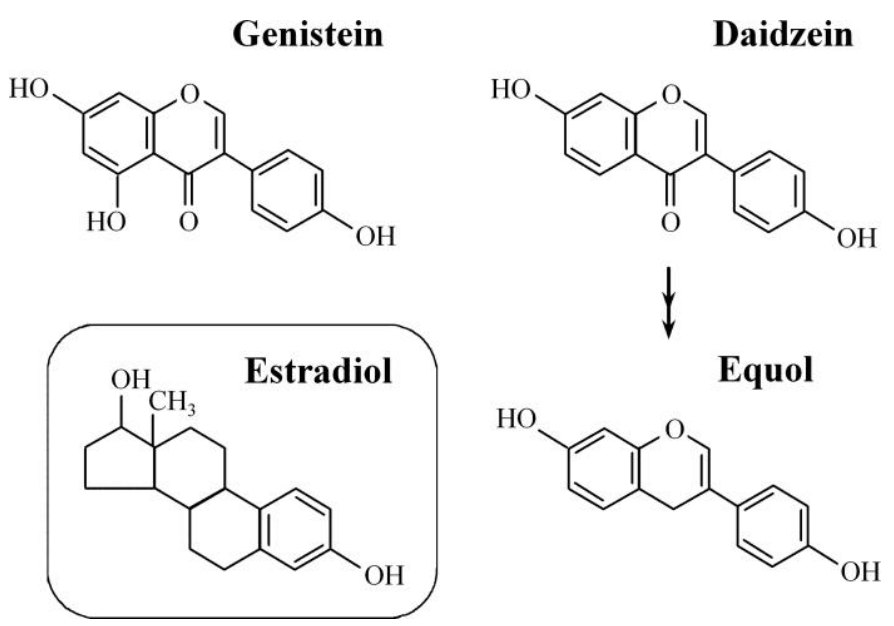

Figure 1. Chemical structures of the soy isoflavonoids genistein, daidzein, and equol compared with estradiol. These isoflavonoids show non-steroidal structure, however, they are able to bind to the human estrogen receptors (Wood CE et al., 2006).

Plant sterols are important materials for insects to synthesize their own hormones. From phytosterols, honeybees are able to produce ecdysteroids that regulate molting, metamorphosis and reproduction (Fig. 2). 


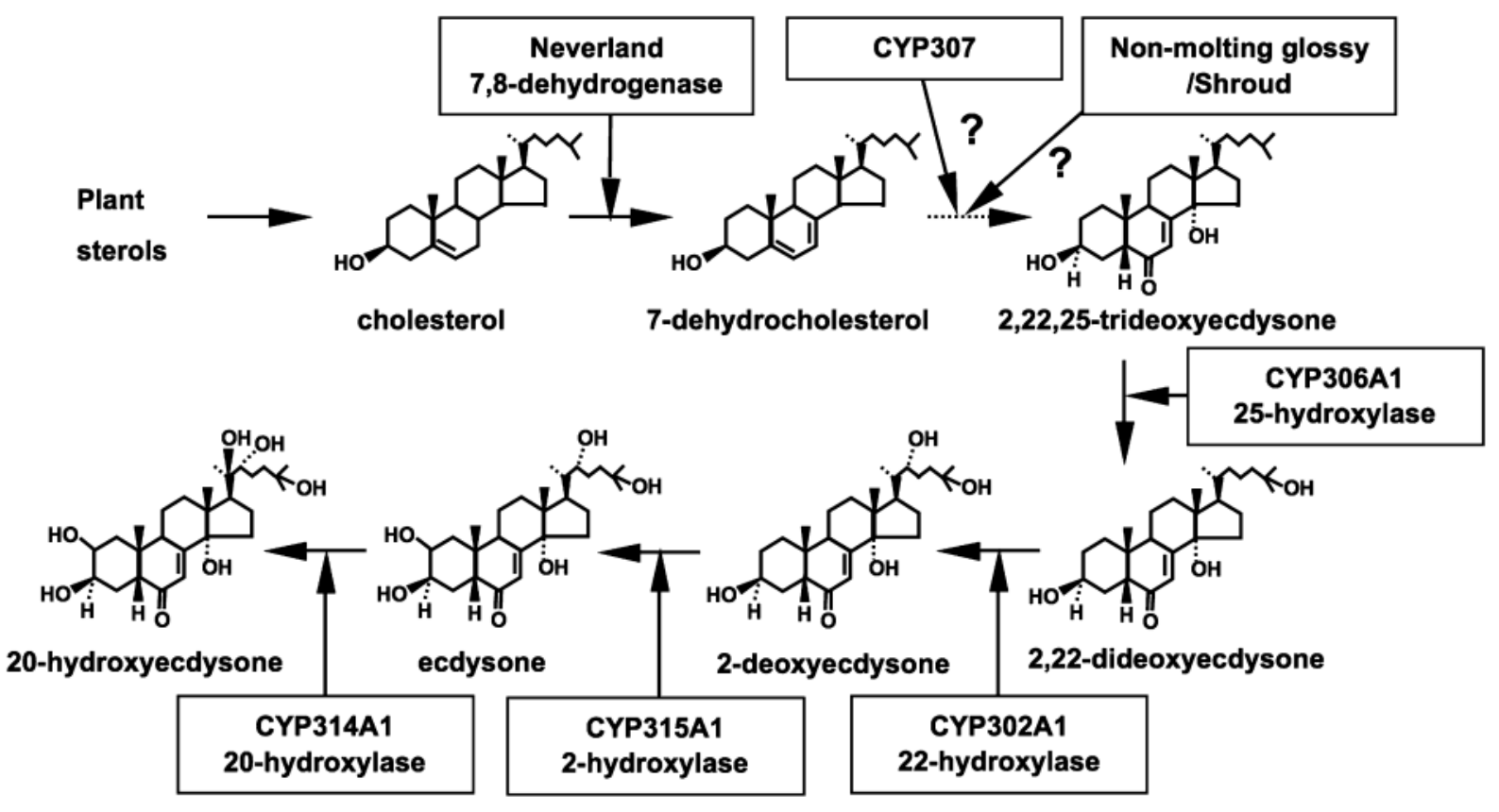

Figure 2. Theoretical pathway of the biosynthesis of 20-hydroxyecdisone in insects (Yamazaki et al., 2011).

These ecdysteroids are also synthesized by the honeybee queen ovaries (Hartfelder et al., 2002). Ecdysteroids such as 20-hydroxyecdysone show protein synthesis-stimulating effect in mammals, but its androgenic effect is absent (Bathori et al., 2008).

Phytoestrogens are widely known, but the concept of phytoandrogens is relatively new (Edouard et al., 2014). Ong \& Tan reported the androgenic effect of Eucommia ulmoides cortex as a novel phytoandrogen compound (Ong \& Tan, 2007). This phytoandrogenic activity was being mediated by triterpenoids and surprisingly, synergistic effect was observed, when Eucommia ulmoides extract and dihydrotestosterone were used in combination. Besides of these facts, several natural substances with androgenic activity have been reported and these extracts and compounds are predominantly used as aphrodisiacs. Korean Red ginseng extract can be an effective alternative therapy for treating erectile dysfunction (ED) (Choi et al., 1999; Jang et al., 2008). It can act through multiple mechanisms, the relaxing effect might be mediated by NO production, but it is not related to sexual hormone levels (de Andrade et al., 2007; Cho et al., 2013). The other aphrodisiac is the yohimbine, an $\alpha_{2}$-adrenocepor antagonist (from Rauwolfia serpentina), which can be also effective in the treatment of ED (Tam et al., 2001). The mechanism of yohimbine action in regulating ED, is a combined effect on the central nervous system and peripheral effects (Saad et al., 2013).

However, there are a lot of plants or extracts of plants, which can be used as aphrodisiacs, for example Turnera diffusa extract (Estrada-Reyes et al., 2009) and nowadays very intensively 
investigated Tribulus terrestris extract (Gauthaman et al., 2002; Chhatre et al., 2014). The effects of all of these compounds and extracts were utilized first in folk medicine and were later proved by evidence-based medicine, and the majority of them are currently available as medical products.

\subsection{Honeybee products in medicine}

Numerous honeybee (Apis mellifera) products, such honey, propolis and bee venom, have been used in traditional medicine to prevent or treat illness and promote healing. The honey has been used since ancient times as part of traditional medicine for the treatment of common cold (Allan \& Arroll, 2014) and cough (Paul et al., 2007) and is used in modern medicine to treat wounds (Majtan, 2014), among other uses. The other, widely investigated honeybee product is the propolis. Propolis provides several beneficial effects on human health, it shows for example antifungal, antibacterial and anti-inflammatory activity (Wagh, 2013). Bee venom also has been used in traditional medicine to treat diseases, such as arthritis, pain, tumors and skin diseases via its anti-inflammatory, antinociceptive and anticancer activities (Son et al., 2007; Oršolić, 2012).

Nowadays, one of the most intensively studied beehive products is the royal jelly (RJ). RJ is the essential food for the queen bee pupa and the queen and it is secreted by the hypopharyngeal and mandibular glands of worker honeybees. It is known, that the fertility of honeybees is mainly driven by the quality and quantity of their food, accordingly when bee larvae are nourished with RJ, they differentiate into queens. The adult queens also consume a high amount of RJ, which contributes to the maintenance of their fertility (Kamakura, 2011; Remolina \& Hughes, 2008). These facts and the traditional usage of RJ in the treatment of menopausal symptoms suggested that RJ may possibly have some estrogen-like effect. In fact, in vitro and in vivo estrogenic effects of raw RJ have been described (Mishima et al., 2005) and its isolated effective compounds (10-hydroxy-trans-2-decenoic acid and its derivatives) exhibit weak ER binding affinities (Suzuki et al., 2008).

\subsection{Drone milk}

Drone milk (DM) is a relatively little-known honeybee product that is secreted (similarly to $\mathrm{RJ})$ by the hypopharyngeal and mandibular glands of the worker honeybees. DM is main 
component of drone brood which also contains larvae and pupae of drones in the comb (Mutsaers et al., 2005a). DM is a light yellow, slightly sweet, thick liquid which is separated from drone brood by extraction to eliminate larvae and pupae during the harvest.

$\mathrm{DM}$ is an essential food of the drone larvae and drone honeybees, and its consumption is presumed to be related to the fertility of drones. Although our knowledge of the effects of DM is very limited, a drone brood preparation is traditionally used in Romania for the rehabilitation and activation of aged people and to treat neurovegetative and sexual problems (Bogdanov, 2011). Data have been reported on the hormone-like strengthening effects of the drone larvae and brood in Eastern European and Asian folk medicine (Mutsaers et al., 2005b) and Yucel et al. have described the androgenic and anabolic effects of Apilarnil (drone bee larvae) on male broilers (Yucel et al., 2011; Altan et al., 2013).

The folk medicine experience and the previously described data suggest the putative hormone-like activity of DM. 


\section{Aims}

The purpose of this work was to investigate the sexual hormone-like effects of DM on rats and to confirm the folk medicine experience. Therefore the following aims were set:

1. The primary aim of this work was to investigate the androgenic effect of raw DM in castrated rats using Hershberger assay. To verifying of the in vivo results we wanted to examine the prostatic mRNA and protein expression of the androgen-dependent Spot14-like androgen-inducible protein (SLAP) with real-time reverse transcription polymerase chain reaction (RT-PCR) and Western blot techniques. After the androgenic effect of crude DM was proven, we wanted to identify the compounds responsible for its hormonal effect, therefore gas chromatography-high-resolution mass spectrometry (GC-HRMS) and nuclear magnetic resonance spectroscopy (NMR) investigations were performed to identify the active component(s) gained by bioactivity-guided fractionation.

2. We set to determine the estrogenic effect of crude DM in female rats using uterotrophic assay. After the in vivo results, we wanted to test the expression of estrogen-dependent Complement component 3 (C3) in the rats uteri with real-time RTPCR and Western blot techniques. Finally, similarly to the androgenic effect of DM, we wanted to identify the effective compound(s) using bioactivity-guided fractionation, high-resolution electrospray ionization-mass spectrometry (HR-ESIMS) and NMR.

3. Our third aim was to investigate the gestagenic effect of DM with pregnancy maintenance assay. Real-time RT-PCR and Western blot techniques were used to determine the expression of the gestagen-sensitive Calcitonin receptor-like receptor (CRLR) in rats uteri. 


\section{Materials and methods}

\subsection{Animals}

Animal investigations were carried out with the approval of the Hungarian Ethical Committee for Animal Research (permission numbers: IV/01758-0/2008 and IV./198/2013.). The animals were treated in accordance with the European Communities Council Directives (86/609/ECC) and the Hungarian Act for the Protection of Animals in Research (XXVIII. tv. 32.§).

For all experiments, Sprague-Dawley rats were purchased from the Charles River Laboratories (Budapest, Hungary) and were housed under controlled temperature $\left(20-23{ }^{\circ} \mathrm{C}\right)$, in humidity (40-60\%)- and light (12 h light/dark regime)- regulated rooms. The animals were maintained on tap water and rodent pellet diet (Charles River Laboratories, Budapest, Hungary) ad libitum. They were acclimatized to the animal house for 7 days prior to the investigations. All of the rats were sacrificed under deep isoflurane (Abbott Laboratories, Abbott Park, IL, USA) anesthesia by exsanguination.

\subsection{Collection of drone milk}

DM was prepared during rape blooming and harvested by the separation from drone larvae and pupae in the late spring (the middle of May) by Sándor Polgár (a professional Hungarian beekeeper). DM - similarly to honey - is extracted from the comb using centrifugal force. The raw liquid material was divided into plastic tubes and was stored at $-20{ }^{\circ} \mathrm{C}$ until the beginning of the investigation and it was diluted with distilled water in all animal experiments.

\subsection{Investigation of androgenic effect}

\subsubsection{Hershberger assay}

Androgenic activity was investigated by a simplified Hershberger assay (Freyberger et al., 2007; Tinwell et al., 2007; Moon et al., 2009). Mature male Sprague-Dawley rats (230-240 g) were anesthetized through the inhalation of 3\% isoflurane vapor (Abbott Laboratories, Abbott Park, IL, USA) via a Burtons anesthetic machine (Guardian Industrial Estate, Marden, U.K.). Castration was performed animals underwent surgically, and the animals were treated locally 
with pefloxacine to avoid infective complications. Pefloxacine injection (Peflacine ${ }^{\circledR}$ ) was purchased from EGIS Pharmaceutical Industry, Budapest, Hungary.

After 10 days, healthy rats were assigned to 6 groups ( $n=18$ per group) by body weight. Body weights were recorded on days 1, 4, 7 and 10 of the study. The animals were treated with the investigated compounds once daily for 10 consecutive days. Testosterone (Sigma Aldrich, Budapest, Hungary) was dissolved in olive oil. When methyl palmitate (MP) and methyl oleate (MO) (Sigma Aldrich, Budapest, Hungary) were involved in the simplified Hershberger assay, the compound was administered in olive oil by oral gavage. Flutamide (Sigma Aldrich, Budapest, Hungary) was suspended in mucilage methylcellulose $(0.5 \%$; Sigma Aldrich, Budapest, Hungary). In a preliminary experiment, DM was administered at three doses $(11,110$ or $1100 \mathrm{mg} / \mathrm{kg} / \mathrm{day})$, and it was found that the $110 \mathrm{mg} / \mathrm{kg} / \mathrm{day}$ dose led to increases in the weights of androgen-sensitive organs. The administration protocol for the raw DM administration is outlined in Table 1.

\begin{tabular}{|c|c|c|c|}
\hline Group & Treatment & Dose & Dosing route \\
\hline $\mathbf{1}$ & water & $1 \mathrm{~mL} / \mathrm{day}$ & p.o. \\
\hline $\mathbf{2}$ & DM & $110 \mathrm{mg} / \mathrm{kg} /$ day & p.o. \\
\hline $\mathbf{3}$ & flutamide & $3 \mathrm{mg} / \mathrm{kg} /$ day & p.o. \\
\hline $\mathbf{4}$ & flutamide $+\mathrm{DM}$ & $3 \mathrm{mg} / \mathrm{kg} /$ day $+110 \mathrm{mg} / \mathrm{kg} /$ day & p.o. \\
\hline $\mathbf{5}$ & testosterone & $0.4 \mathrm{mg} / \mathrm{kg} /$ day & s.c. $^{2}$ \\
\hline $\mathbf{6}$ & flutamide + testosterone & $3 \mathrm{mg} / \mathrm{kg} /$ day $+0.4 \mathrm{mg} / \mathrm{kg} /$ day & p.o. + s.c. \\
\hline
\end{tabular}

Table 1. Administration protocol in Hershberger assay.

${ }^{1}$ p.o.: orally, ${ }^{2}$ s.c.: subcutaneously

One day after the final treatment, the rats were sacrificed under deep isoflurane anesthesia by exsanguination. Androgen-dependent organs (the glans penis, seminal vesicle, ventral prostate and levator ani muscle) were removed, trimmed free of fat and adjacent tissue and weighed on an HR-202 analytical scale (A\&D Instruments, Oxfordshire, UK). Organ weights were expressed as relative weights (organ weight $\mathrm{mg} / 100 \mathrm{~g}$ body weight). 


\subsubsection{Plasma testosterone assay}

Before the exsanguinations, $1 \mathrm{~mL}$ of blood was taken from each of 5 animals in each group by cardiac puncture under deep isoflurane anesthesia. Blood samples were collected in BD Vacutainer tubes (Belliver Industrial Estate, Plymouth, UK) and centrifuged (CR-132, Jouan, Saint-Herblain, France) at $1500 \mathrm{~g}$ for $10 \mathrm{~min}$ to separate the plasma. Plasma samples were stored at $-70{ }^{\circ} \mathrm{C}$ until assay. Plasma testosterone levels were determined with a testosterone EIA kit (Cayman Chemical Company, Ann Arbor, MI, USA). Absorbancies were measured with a SPECTROstar Nano microplate reader (BMG Labtech, Offenburg, Germany).

\subsubsection{Determination of prostatic Slap mRNA by real-time RT-PCR}

Mature male Sprague-Dawley rats (400-420 g) were castrated. After 7 days, healthy rats were randomized and assigned to 3 groups ( $n=5$ per group) by body weight. The animals were treated once daily for 5 consecutive days with DM $(110 \mathrm{mg} / \mathrm{kg}$ orally) or testosterone (1.67 mg/animal subcutaneously). The control group was treated with the vehicle of the DM (distilled water) orally. One day after the final treatment, the rats were sacrificed, and ventral prostate tissues were removed and frozen in liquid nitrogen.

The tissues were homogenized mechanically. Total RNAs from tissues were extracted by using a TRIsure Kit (Bioline Reagents Ltd., London, UK). The quality and quantity of the RNA were assessed at wavelengths of 260/280 nm, and all samples exhibited an absorbency ratio in the range 1.6-2.0.

$1 \mu \mathrm{g}$ of total RNA and the TaqMan RNA-to-CT 1-Step Kit (Applied Biosystems, Budapest, Hungary) were used for reverse transcription and amplification. The following primers were used: assay ID Rn01756639_g1 (Amplicon Length: 71) for Slap and Rn99999916_s1 for $\beta$ actin as endogenous control. RT-PCR was performed with an ABI StepOne Real-Time cycler (Applied Biosystems, Budapest, Hungary). The fluorescence intensities of the probes were plotted against PCR cycle numbers. The amplification cycle displaying the first significant increase in the fluorescence signal was defined as the threshold cycle (CT). 


\subsubsection{Western blot analysis}

Mature male rats $(320-350 \mathrm{~g})$ were castrated and treated as described previously (section 3.3.3). Ventral prostate tissues were powdered with a Sartorius Mikro Dismembrator U (Sartorius, Goettingen, Germany) and homogenized in RIPA Lysis Buffer combined with PMSF solution, sodium orthovanadate solution and protease inhibitor cocktail solution (Santa Cruz Biotechnology Inc., Santa Cruz, CA, USA). Samples were centrifuged at 100,000 x g for $1 \mathrm{~h}$, and the supernatant was used to measure total protein (cytosolic fraction). The precipitate was resuspended in the original volume of the buffer and was used as a total membrane fraction. $50 \mu \mathrm{g}$ of protein per well was subjected to electrophoresis on 4-12\% NuPAGE BisTris Gel in XCell SureLock Mini-Cell Units (Life Technologies, Budapest, Hungary). Proteins were transferred from gels to nitrocellulose membranes by using the iBlot Gel Transfer System (Life Technologies, Budapest, Hungary). Antibody binding was detected with the WesternBreeze Chromogenic Western Blot Immundetection Kit (Life Technologies, Budapest, Hungary). The blots were incubated on a shaker with SLAP and $\beta$-ACTIN polyclonal antibody (Santa Cruz Biotechnology, Santa Cruz, CA, USA; 1:200) in the blocking buffer. The optical density of each immunoreactive band was determined with Kodak 1D Images analysis software (Carestream Health, Inc., Rochester, NY, USA). Optical densities were calculated as arbitrary units after local area background subtraction.

\subsubsection{Bioactivity-guided fractionation}

The crude DM was diluted with water $(165 \mathrm{~mL})$, extracted with petroleum ether $(5 \mathrm{x} 200 \mathrm{~mL})$ and re-extracted with water $(3 \times 10 \mathrm{~mL})$. The combined aqueous phase was applied to an octadecyl-silica column (250 g, 0.06-0.02 $\mu \mathrm{m}$; ChemieUetikon-C-Gel, Chemie Uetikon, Uetikon am See, Switzerland) and subjected to low-pressure reversed-phase column chromatography (RPCC). Gradient elution was performed with water, 20\% (I/A), 40\%, 60\% and $80 \%(\mathrm{I} / \mathrm{B})$ aqueous methanol $(\mathrm{MeOH} ; 700 \mathrm{~mL}$ each), 100\% $\mathrm{MeOH}(\mathrm{I} / \mathrm{C}, 1000 \mathrm{~mL})$ and dichloromethane (I/D, $1000 \mathrm{~mL})$.

Fractions I/B and I/C eluted from the reversed-phase column with $\mathrm{MeOH}$ were evaporated to dryness. The residues of I/B $(0.0143 \mathrm{~g})$ and I/C $(0.94 \mathrm{~g})$ were dissolved in $50 \%$ aqueous acetone and further fractionated through repeated low-pressure RPCC (20 g, LiCroprep RP-18 40-63 $\mu \mathrm{m}$, E. Merck, Darmstadt, Germany). To determine the elution range of the sample 
constituents, a pre-chromatographic separation with a small sample on RPCC was used and the androgenic activity of the fraction was controlled by real-time RT-PCR, as described above (section 3.3.3). The active constituents of I/B and I/C were eluted with $75 \%$ aqueous acetone. Unfortunately, the separation products of fraction $\mathrm{I} / \mathrm{B}$ were found later to be ineffective, and the codes of these products are therefore not mentioned further. The whole of fraction I/C was separated. The elution was started with a weaker solvent system than $75 \%$ aqueous acetone (70\% aqueous acetone (II/A) $200 \mathrm{~mL}$ ) and this was followed by $75 \%$ aqueous acetone (II/B, II/C, II/D and II/E). A large volume of this latter solvent system (900 $\mathrm{mL})$ was used to the elution. Finally, the column was washed with acetone (II/F) $(150 \mathrm{~mL})$ and dichloromethane $(150 \mathrm{~mL})$. The active fraction (II/E) eluted with $75 \%$ aqueous acetone was evaporated to dryness and the residue $(0.0669 \mathrm{~g})$ was analyzed by thin-layer chromatography (TLC), MS and NMR. The whole separation procedure was controlled by RP TLC (TLC systems 1 and 2). RP TLC was performed on 20 x $20 \mathrm{~cm}$ glass TLC plates coated with RP-18WF254 (E. Merck, Darmstadt, Germany) at room temperature by an ascending technique with a mobile phase: TLC system 1: acetone-water $(95: 5 \mathrm{v} / \mathrm{v})$, TLC system 2: tetrahydrofuran-water $(7: 3 \mathrm{v} / \mathrm{v})$. The separation was detected by the use of a vanillin-sulfuric acid spray reagent. The quantities of the residues and their doses for oral administration are shown in Table 2.

\begin{tabular}{|c|c|c|c|c|}
\hline Fraction & Initial amount (g) & Amount of fraction (mg) & Dose (mg/kg) & Vehicle \\
\hline I/A & 16.20 & 310.0 & 4.330 & MM $^{1}$ \\
\hline I/B & 16.20 & 10.0 & 0.140 & MM \\
\hline I/C & 16.20 & 60.0 & 0.833 & MM \\
\hline I/D & 16.20 & 880.0 & 12.333 & olive oil \\
\hline II/A & 178.16 & 7.2 & 0.010 & MM \\
\hline II/B & 178.16 & 14.2 & 0.018 & MM \\
\hline II/C & 178.16 & 131.1 & 0.167 & olive oil \\
\hline II/D & 178.16 & 13.7 & 0.017 & olive oil \\
\hline II/E & 178.16 & 66.9 & 0.083 & olive oil \\
\hline II/F & 178.16 & 940.0 & 1.200 & MM \\
\hline
\end{tabular}

Table 2. The fractions gained from drone milk and their oral doses for rats.

I/A: $20 \%$ aqueous $\mathrm{MeOH}$ fraction; I/B: $40 \%, 60 \%$ and $80 \%$ aqueous $\mathrm{MeOH}$ fraction; I/C: $100 \% \mathrm{MeOH}$ fraction; I/D: dichloromethane fraction; II/A: 70\% aqueous acetone fraction; II/B, II/C, II/D and II/E: 75\% aqueous acetone fractions; II/F: 100\% acetone fraction; ${ }^{1} \mathrm{MM}$ : mucilage methylcellulose. 


\subsubsection{HRMS and NMR spectroscopy}

GC-HRMS analyses were performed on a Waters GCT-Premier (Waters Corporation, Milford, MA, USA) mass spectrometer. The column used was a DB-5 $30 \mathrm{~m} \times 0.25 \mathrm{~mm}$ capillary column with a film thickness of $0.25 \mu \mathrm{m}$ (Agilent Technologies, Santa Clara, CA, USA). The temperature program was set to begin at $50{ }^{\circ} \mathrm{C}$ for $1 \mathrm{~min}$, followed by an elevation at $25{ }^{\circ} \mathrm{C} / \mathrm{min}$ to $300{ }^{\circ} \mathrm{C}$ (maintained for $10 \mathrm{~min}$ ). The carrier gas used was helium at a flow rate of $1 \mathrm{~mL} / \mathrm{min}$. The data acquisition software used was MassLynx V.4.1. (Waters Inc., Milford, MA, USA). Electron ionization was used at $70 \mathrm{eV}$ in positive mode and the mass spectrometer was set to full scan, $\mathrm{m} / \mathrm{z}$ 40-600.

NMR spectra were recorded in $\mathrm{MeOH}-d 4$ at $298 \mathrm{~K}$ with a Varian $800 \mathrm{MHz}$ NMR spectrometer equipped with a $5 \mathrm{~mm}{ }^{1} \mathrm{H}\left({ }^{13} \mathrm{C} /{ }^{15} \mathrm{~N}\right)$ Triple Resonance ${ }^{13} \mathrm{C}$ Enhanced Salt Tolerant Cold Probe, operating at 800 and $201 \mathrm{MHz}$ for ${ }^{1} \mathrm{H}$ and ${ }^{13} \mathrm{C}$ nuclei, respectively. Chemical shifts are reported in ppm relative to residual solvent signals $\left(3.31 \mathrm{ppm}\right.$ in ${ }^{1} \mathrm{H}$ and $49.15 \mathrm{ppm}$ in ${ }^{13} \mathrm{C}$ ). Standard one and two-dimensional pulse sequences available in the VNMRJ software package were applied in all cases.

\subsubsection{Statistical analysis}

Statistical analyses were performed with the Prism 4.0 software. All body and organ weights, plasma testosterone data, mRNA and protein expressions of SLAP were analyzed by one-way ANOVA, followed by Dunnett's test, and each is presented as the mean \pm standard error of the mean (SEM). Significance was accepted at $p<0.05$.

\subsection{Investigation of estrogenic effect}

\subsubsection{Uterotrophic assay}

Uterotrophic assays were performed in accordance with the protocol described by Kanno et al. and Song et al. (Kanno et al. 2001; Song et al. 2002). Immature female Sprague-Dawley rats (20-21 days old) were randomly assigned to one or other of 6 groups $(n=10)$ and were treated once daily for 4 consecutive days with the test compounds. No treatment-related clinical signs or abnormal changes were observed in any of the groups. The soy extract (Aktiv 
Meno Capsules, Drogerie Markt, Karlsruhe, Germany) was suspended in $0.5 \%$ mucilage methylcellulose (MM; Sigma Aldrich, Budapest, Hungary). Each soy isoflavone capsule contained $25 \mathrm{mg}$ of soy isoflavone, several vitamins (C, E, biotin and folic acid) and minerals (dicalcium phosphate and zinc oxide) in powder form. 17ß-estradiol valerate $\left(\mathrm{E}_{2}\right.$; Sigma Aldrich, Budapest, Hungary) as positive control and ICI 182.780, an estrogenic antagonist (ICI; Sigma Aldrich, Budapest, Hungary) were administered by subcutaneous injection. The control group was treated orally with distilled water. The administration protocol is outlined in Table 3.

\begin{tabular}{|c|c|c|c|}
\hline Group & Treatment & Dose & Dosing route \\
\hline $\mathbf{1}$ & water & $0.5 \mathrm{~mL} /$ day & p.o. $^{{ }^{\prime}}$ \\
\hline $\mathbf{2}$ & $\mathrm{DM}$ & $570 \mathrm{mg} / \mathrm{kg} /$ day & p.o. \\
\hline $\mathbf{3}$ & $\mathrm{DM}+\mathrm{ICI}$ & $570 \mathrm{mg} / \mathrm{kg} / \mathrm{day}+400 \mu \mathrm{g} / \mathrm{kg} /$ day & ${\text { p.o. }+ \text { s.c. }^{2}}^{2}$ \\
\hline $\mathbf{4}$ & $\mathrm{E}_{2}$ & $3.9 \mu \mathrm{g} / \mathrm{kg} / \mathrm{day}$ & s.c. \\
\hline $\mathbf{5}$ & $\mathrm{E}_{2}+\mathrm{ICI}$ & $3.9 \mu \mathrm{g} / \mathrm{kg} / \mathrm{day}+400 \mu \mathrm{g} / \mathrm{kg} /$ day & s.c. + s.c. \\
\hline $\mathbf{6}$ & soy isoflavones & $500 \mathrm{mg} / \mathrm{kg} / \mathrm{day}$ & p.o. \\
\hline
\end{tabular}

Table 3. Treatments and dosages of raw drone milk for immature rats.

${ }^{1}$ p.o.: orally, ${ }^{2}$ s.c.: subcutaneously

One day after the final treatment, the rats were sacrificed, their uteri were removed and weighed. Uterus weights were expressed as relative weights (organ weight $\mathrm{mg} / 100 \mathrm{~g}$ body weight).

\subsubsection{Determination of C3 mRNA by real-time RT-PCR}

Mature female rats (160-180 g) were ovariectomized under isoflurane anesthesia 8 days prior to treatment. The animals were randomly grouped $(n=6)$ and were treated once daily for 2 days with $\mathrm{E}_{2}(96.2 \mu \mathrm{g} / \mathrm{kg} /$ day $), \mathrm{DM}(0.5 \mathrm{~g} / \mathrm{kg} / \mathrm{day})$ or vehicle only. One day after the final treatment, the rats were sacrificed by exsanguination under deep isoflurane anesthesia. The uteri were removed, trimmed free of fat and adjacent tissue. The uterus samples were stored at $4{ }^{\circ} \mathrm{C}$ overnight in RNAlater solution (Life Technologies, Budapest, Hungary), the supernatant was then removed, and the samples were stored at $-70{ }^{\circ} \mathrm{C}$ until the beginning of the investigation. 
Total RNA was isolated from uterus tissue by using the TRI Reagent (Molecular Research Center, Inc., Cincinnati, OH, USA). The quality and the quantity of RNA were assessed via the ratio of the absorbances at 260 and $280 \mathrm{~nm}$; all samples exhibited ratios in the range 1.62.0. With $1 \mu \mathrm{g}$ total RNA, cDNA was first synthetized by reverse transcription using the High-capacity RNA-to-cDNA Kit (Life Technologies, Budapest, Hungary). Samples were subjected to $37^{\circ} \mathrm{C}$ for $60 \mathrm{~min}, 95^{\circ} \mathrm{C}$ for $5 \mathrm{~min}$, and $4{ }^{\circ} \mathrm{C}$ for $5 \mathrm{~min}$. The cDNA was stored at $20{ }^{\circ} \mathrm{C}$. Amplification of the PCR products (C3 Rn00566466_m1) and GAPDH primer (Rn99999916_s1) as endogenous control was performed with the TaqMan Gene Expression Master Mix (Life Technologies, Budapest, Hungary) and the ABI StepOne Real-Time cycler. For amplification, the following conditions were used: $50{ }^{\circ} \mathrm{C}$ for $2 \mathrm{~min}, 95{ }^{\circ} \mathrm{C}$ for $10 \mathrm{~min}$ and 40 cycles of $95^{\circ} \mathrm{C}$ for $15 \mathrm{sec}, 60^{\circ} \mathrm{C}$ for $1 \mathrm{~min}$. The fluorescence intensities of the probes were plotted against PCR cycle numbers. The amplification cycle displaying the first significant increase in the fluorescence signal was defined as the CT.

\subsubsection{Western blot analysis}

Mature female rats (160-180 g; n=6 in each group) were ovariectomized and treated as described previously (section 3.4.2). Uterus tissues were used to isolate total protein using the reviewed methods. $20 \mu \mathrm{g}$ of protein per well was subjected to electrophoresis. The blots were incubated on a shaker with C3 and $\beta$-ACTIN polyclonal antibody (Santa Cruz Biotechnology, Santa Cruz, CA, USA; 1:200) in the blocking buffer. The optical density of each immunoreactive band was determined with Kodak 1D Images analysis software as previously mentioned (section 3.3.4)

\subsubsection{Fractionation of $\mathrm{DM}$}

The crude DM was diluted with water and extracted with petroleum ether as already described (section 3.3.5). Gradient elution was performed with water, 20\% (I/A), 40-60-80\% (I/B) aqueous $\mathrm{MeOH}(700 \mathrm{~mL}$ each), $\mathrm{MeOH}(\mathrm{I} / \mathrm{C})(1000 \mathrm{~mL})$ and dichloromethane (I/D) (1000 $\mathrm{mL}$ ). The fractions eluted from the reversed-phase column with $20 \%, 40 \%, 60 \%, 80 \%$ of aqueous $\mathrm{MeOH}$ were combined and evaporated to dryness. The residue (2.86 g) was further fractionated through repeated low-pressure RPCC. Elution was carried out with different mixtures of aqueous $\mathrm{MeOH}$, using stepwise gradient elution with 5\% or $10 \%$ increases of the 
MeoH content in each step $(10 \%, 15 \%, 20 \%, 25 \%, 35 \%, 45 \%, 55 \%, 65 \%, 70 \%, 75 \%$ and $80 \%$ ) and finally with $\mathrm{MeOH}$. The fractions eluted with 20\% (II/A), 35\% (II/B), 70\% (II/C) or $75 \%$ (II/D) aqueous $\mathrm{MeOH}$ were further examined by uterotrophic assay to determine the estrogenic activity. The most active fraction (II/B) eluted with $35 \%$ aqueous $\mathrm{MeOH}$ was further purified on a preparative scale by RP (C18) TLC using tetrahydrofuran-water $6: 4 \mathrm{v} / \mathrm{v}$ (TLC System 3). The band at $\mathrm{R}_{\mathrm{F}}=0.41$ was scraped off and the substances were eluted from the sorbent with $\mathrm{MeOH}$. The solution obtained was evaporated to dryness and the residue (0.06 g) was analyzed by TLC, MS and NMR.

As already mentioned, the whole separation procedure was controlled by RP TLC and the compounds were detected by the use of a vanillin-sulfuric acid spray reagent. Table 4 shows the administration protocol of bioactivity-guided fractions. The control groups $(n=10)$ were treated with either $0.5 \% \mathrm{MM}$ or olive oil.

\begin{tabular}{|c|c|c|c|c|}
\hline Fraction & Initial amount (g) & Amount of fraction (mg) & Dose (mg/kg) & Vehicle \\
\hline I/A & 16.20 & 310.0 & 26.000 & MM $^{1}$ \\
\hline I/B & 16.20 & 10.0 & 0.840 & MM \\
\hline I/C & 16.20 & 60.0 & 5.000 & MM \\
\hline I/D & 16.20 & 880.0 & 74.000 & olive oil \\
\hline II/A & 178.16 & 15.9 & 0.121 & MM \\
\hline II/B & 178.16 & 60.0 & 0.458 & MM \\
\hline II/C & 178.16 & 14.3 & 0.109 & olive oil \\
\hline II/D & 178.16 & 14.6 & 0.111 & olive oil \\
\hline
\end{tabular}

Table 4. Parameters and oral dosages of drone milk fractions for immature rats.

I/A: $20 \%$ aqueous $\mathrm{MeOH}$ fraction; I/B: $40 \%, 60 \%$ and $80 \%$ aqueous $\mathrm{MeOH}$ fraction; I/C: $100 \% \mathrm{MeOH}$ fraction; I/D: dichloromethane fraction; II/A: 20\% aqueous $\mathrm{MeOH}$ fraction; II/B: 35\% aqueous MeOH fraction; II/C: 70\% aqueous $\mathrm{MeOH}$ fraction; II/D: $75 \%$ aqueous $\mathrm{MeOH}$ fraction; ${ }^{1} \mathrm{MM}$ : mucilage methylcellulose.

\subsubsection{HRMS and NMR analyses}

HRMS analyses were performed on an LTQ FT Ultra (Thermo Fisher Scientific, Bremen, Germany) spectrometer. Ionization was achieved with ESI, operated in the positive ion mode. The ion transfer capillary temperature was set at $280{ }^{\circ} \mathrm{C}$, and the capillary voltage for each measurement was $4.1 \mathrm{kV}$. In CID (collision-induced dissociation) experiments, helium was used as the collision gas, and normalized collision energy (expressed as a percentage), which 
is a measure of the amplitude of the resonance excitation RF voltage applied to the endcaps of the linear ion trap, was used to bring about fragmentation. The sodium adduct of the peak molecular ion was fragmented by CID at a normalized collision energy of 50\%. The sample was dissolved in $\mathrm{MeOH}$. Data acquisition and analysis for HRMS were performed with Xcalibur software version 2.0 (Thermo Fisher Scientific).

NMR spectra were recorded in $\mathrm{MeOH}-d 4$ (Merck, Darmstadt, Germany) in a Shigemi sample tube at $298 \mathrm{~K}$, using a Varian $800 \mathrm{MHz}$ NMR spectrometer equipped with a ${ }^{1} \mathrm{H}\left\{{ }^{13} \mathrm{C} /{ }^{15} \mathrm{~N}\right\}$ Triple Resonance ${ }^{13} \mathrm{C}$ Enhanced Salt Tolerant Cold Probe operating at $800 \mathrm{MHz}$ for ${ }^{1} \mathrm{H}$. Chemical shifts were referenced to the residual solvent resonances $(\delta \mathrm{H}=3.31 \mathrm{ppm}$ and $\delta \mathrm{C}=$ $49.15 \mathrm{ppm})$. Pulse sequences in all experiments [ ${ }^{1} \mathrm{H},{ }^{1} \mathrm{H}$-Presat, GHSQCAD, GHMBCAD, and one- and two-dimensional zTOCSY] were taken from the VNMRJ-3.2 software library without any modification.

\subsubsection{Statistical analysis}

All statistical analyses for biological determinations (uterotrophic assay, RT-PCR and Western blot) were performed with the Prism 4.0 software. All data were analyzed by oneway ANOVA followed by the Newman-Keuls test and each value is reported as a mean \pm SEM. Significance was accepted at $\mathrm{p}<0.05$.

\subsection{Investigation of gestagenic effect}

\subsubsection{Pregnancy maintenance assay}

Mature female (160-180 g) and male (220-240 g) Sprague-Dawley rats were mated in a special mating cage. The presence of pregnancy was determined by the assessment of sperm in the vaginal smear (first day of pregnancy). On day 8 of the pregnancy, the animals were ovariectomized and the numbers of fetuses (implantation sites) were registered. The ovariectomized females were randomly assigned to 3 groups $(n=7)$ and were treated with the test compounds once daily from day 8 to day 14. Table 5 shows the administration protocol of the pregnancy maintenance assay. 


\begin{tabular}{|c|c|c|c|}
\hline Group & Treatment & Dose & Dosing route \\
\hline $\mathbf{1}$ & $\mathrm{P}+\mathrm{E}_{2}$ & $3 \mathrm{mg} / \mathrm{day}+6.6 \mu \mathrm{g} / \mathrm{kg} /$ day & s.c. $^{1}+$ s.c. \\
\hline $\mathbf{2}$ & $\mathrm{E}_{2}$ & $6.6 \mu \mathrm{g} / \mathrm{kg} / \mathrm{day}$ & s.c. \\
\hline $\mathbf{3}$ & $\mathrm{DM}+\mathrm{E}_{2}$ & $0.5 \mathrm{~g} / \mathrm{kg} / \mathrm{day}+6.6 \mu \mathrm{g} / \mathrm{kg} /$ day & p.o. $^{2}+$ s.c. \\
\hline $\mathbf{4}$ & $\mathrm{DM}+\mathrm{SP}$ & $0.5 \mathrm{~g} / \mathrm{kg} /$ day $+20 \mathrm{mg} / \mathrm{kg} /$ day & p.o. + p.o. \\
\hline
\end{tabular}

Table 5. Treatments and dosages of the pregnancy maintenance assay.

${ }^{1}$ s.c.: subcutaneously, ${ }^{2}$ p.o.: orally

On day 15 of pregnancy, the number of surviving fetuses was recorded and was given as a ratio of all fetuses (Arkaravichien \& Kendle 1990; Elger et al., 2003).

\subsubsection{RT-PCR and Western blot measurements}

Mature female rats (160-180 g) were ovariectomized under isoflurane anesthesia 6 days prior to treatment. The animals were randomly grouped and were treated once daily for 3 days with $\mathrm{DM}(0.5 \mathrm{~g} / \mathrm{kg} /$ day) or progesterone ( $\mathrm{P} ; 2 \mathrm{x} 2 \mathrm{mg} /$ day) or vehicle (distilled water) only. Later, the other group of animals was treated with the weak gestagen spironolactone (SP; $2 \times 15$ $\mathrm{mg} / \mathrm{kg} / \mathrm{day})$ and with a combination of DM $(0.5 \mathrm{~g} / \mathrm{kg} / \mathrm{day})$ and $\mathrm{SP}(2 \times 15 \mathrm{mg} / \mathrm{kg} / \mathrm{day})$. One day after the final treatment, the rats were sacrificed and their uteri were removed.

The isolation of total RNA and the amplification of the PCR products CRLR (Rn00562334_m1) and GAPDH primer (Rn99999916_s1) as endogenous control were performed as previously mentioned (section 3.4.2).

The isolation of protein for the Western blot measurement was performed as described previously (section 3.3.4), using CRLR and $\beta$-ACTIN polyclonal antibody (Santa Cruz Biotechnology, Santa Cruz, CA, USA; 1:200) in the blocking buffer.

\subsubsection{Statistical analysis}

All statistical analyses for biological determinations (pregnancy maintenance assay, RT-PCR and Western blot) were performed with the Prism 4.0 software. All data were analyzed by one-way ANOVA followed by the Dunnett's test and each value is reported as a mean $\pm \mathrm{SEM}$. Significance was accepted at $p<0.05$. 


\section{Results}

\subsection{Androgenic effect of drone milk}

\subsubsection{In vivo androgenic effect of crude drone milk}

No treatment-related symptoms or abnormal changes were observed in any of the groups. There was no significant difference between the increases in body weight of the crude DMtreated and non-treated (control) groups. Testosterone treatment increased the body weight as compared with the other groups. Flutamide blocked the body weight-increasing effect of testosterone, but alone did not influence the gain in weight (Fig. 3).

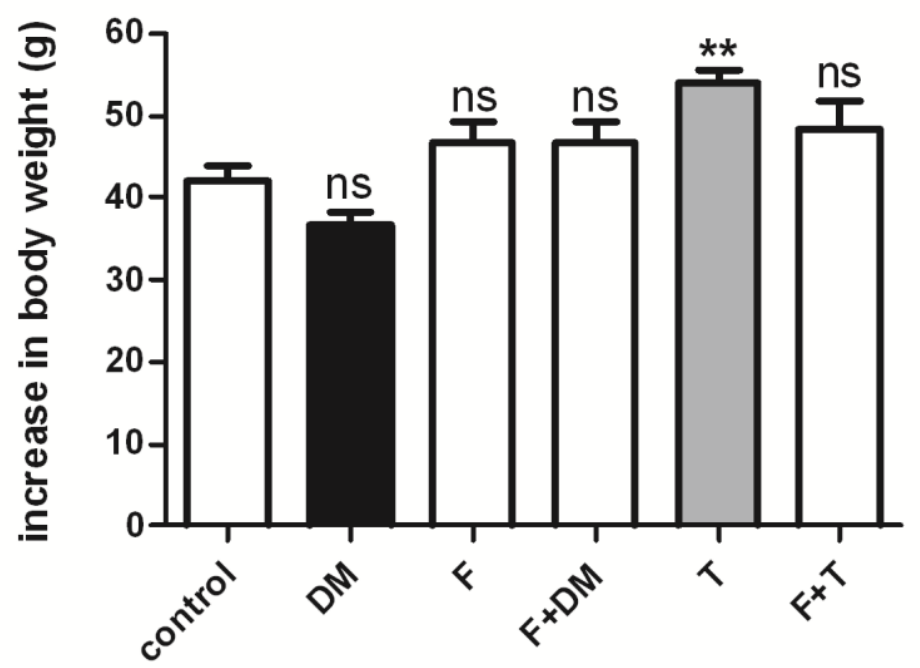

Figure 3. Changes in body weight following treatment with crude drone milk (DM), testosterone (T) and flutamide (F) in castrated male rats. Only testosterone increased the body weight as compared with the control group. $* * \mathrm{p}<0.01 ;$ ns: not significant

The raw DM increased the relative organ weights (wet organ weight $\mathrm{mg} / 100 \mathrm{~g}$ body weight) of the glans penis, seminal vesicle and levator ani muscle in rats. It also increased the average prostate weight, though this change was not statistically significant. Testosterone enhanced all the organ weights, and was more effective than the DM. The organ weights were not changed by flutamide treatment, but flutamide inhibited the organ weight-increasing effect of the DM and blocked the effects of testosterone (Fig. 4). 
A.

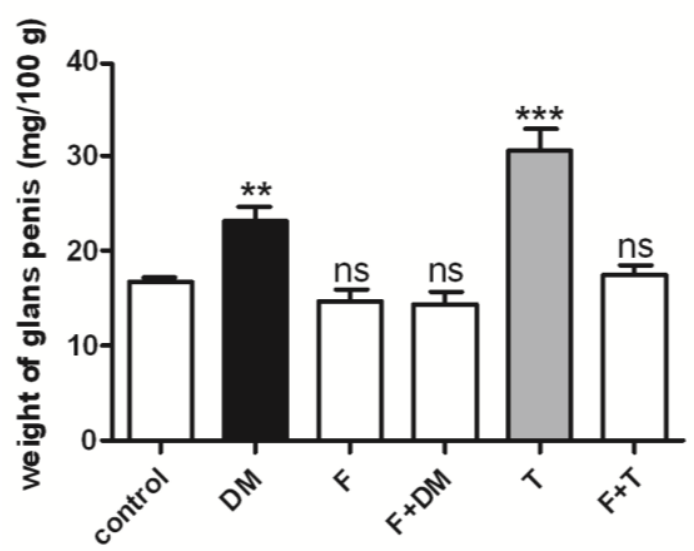

C.

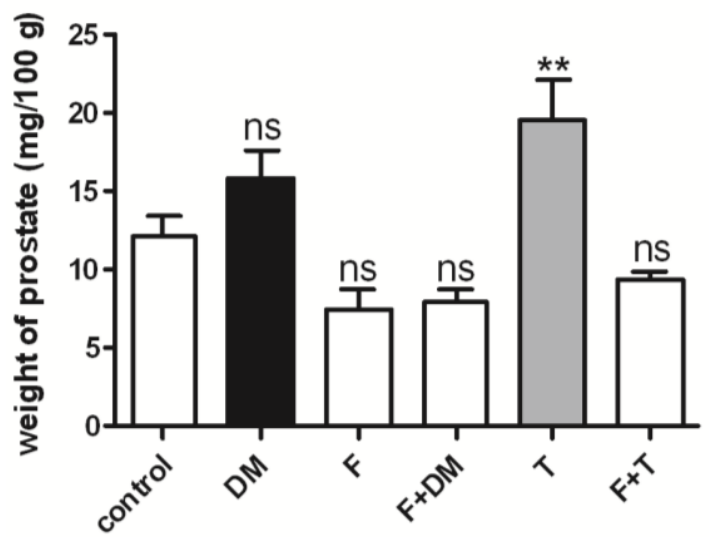

B.
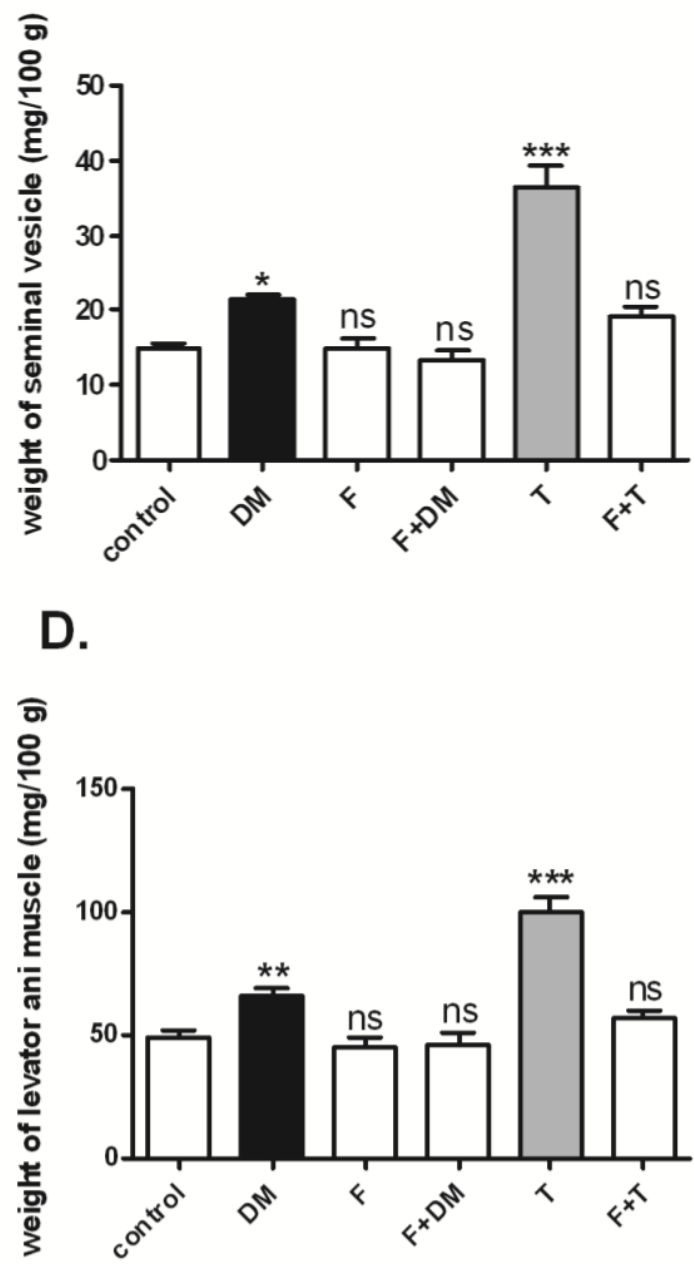

Figure 4. Changes in weight of androgen-sensitive organs following treatment with crude drone milk (DM) and testosterone (T) in castrated male rats. The drone milk and the positive control testosterone increased the relative weights ( $\mathrm{mg} / 100 \mathrm{~g}$ body weight) of the glans penis (A), seminal vesicle (B) and levator ani muscle (D). These effects were flutamide (F)-sensitive in all cases. The raw drone milk, in contrast with testosterone, did not exhibit a significant weight-increasing effect on the prostate $(\mathbf{C}) .{ }^{*} \mathrm{p}<0.05$; ${ }^{* *} \mathrm{p}<0.01$; *** $\mathrm{p}<0.001$; ns: not significant

\subsubsection{Measurement of plasma testosterone level}

Both the raw DM and the testosterone treatment increased the plasma testosterone level. Flutamide treatment blocked the plasma testosterone level-increasing effects of both compounds. After a single administration of flutamide, the hormone level remained unchanged (Fig. 5). 


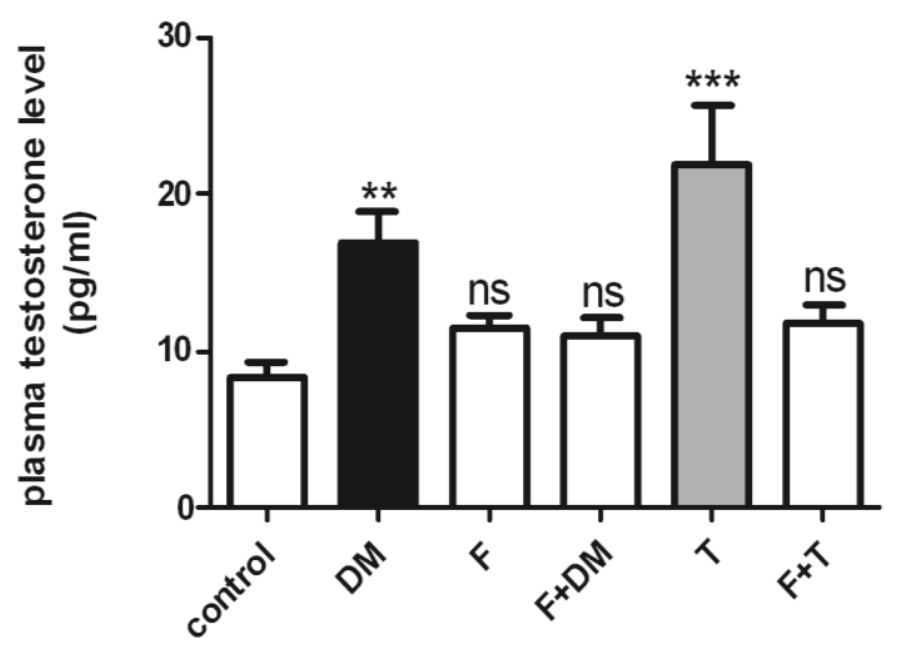

Figure 5. The effects of crude drone milk (DM) treatment on the plasma testosterone (T) level in castrated male rats. The drone milk and the positive control testosterone increased the plasma testosterone levels. Both increases were flutamide $(\mathrm{F})$-sensitive. $* * \mathrm{p}<0.01$; *** $\mathrm{p}<0.001$; ns: not significant

\subsubsection{Measurements of prostatic Slap mRNA and protein}

The crude DM increased the expression of Slap mRNA in ventral prostate, but this effect was significantly lower than that of testosterone. In Western blot measurements, DM was found to increase the level of SLAP in the ventral prostate tissue (Fig. 6).

A.

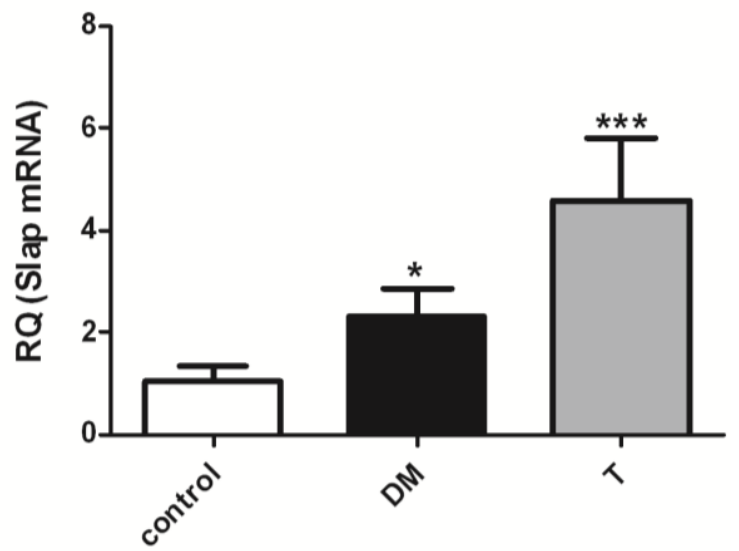

B.

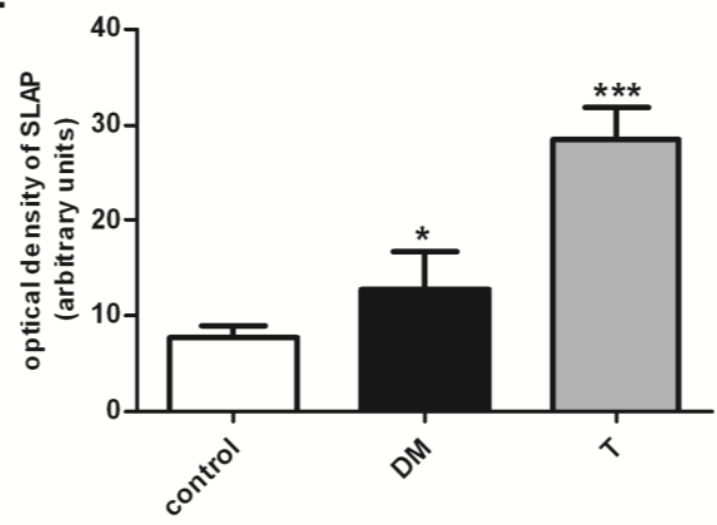


C.

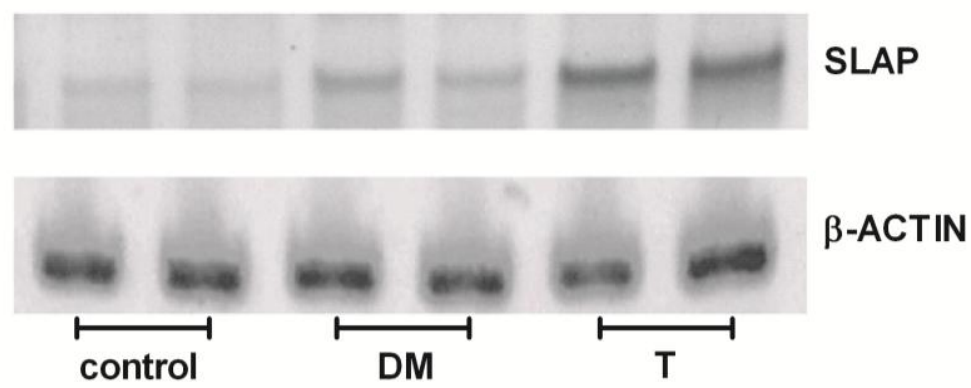

Figure 6. RT-PCR (A) and Western blot (B) analysis of Spot14-like androgen-inducible protein (SLAP) mRNA and protein in rat prostate. The crude drone milk (DM) increased the mRNA expression of the androgen-dependent Slap in rat prostate tissue (A). Western blot analysis (B) revealed the SLAP protein expression-increasing effect of drone milk in the prostate tissue. The representative gel photo (C) shows the change in SLAP proteins in parallel with $\beta$-actin. ${ }^{*} \mathrm{p}<0.05 ; * * * \mathrm{p}<0.001$; RQ: relative quantity

\subsubsection{Bioactivity-guided fractionation}

After clarification of the androgen-like effect of raw DM, we launched bioactivity-guided fractionations to find the effective ingredients of this natural product. As an initial step of DM purification, liquid-liquid partition was used with a high load. The crude DM was extracted with petroleum ether after dilution with water, to remove apolar contaminants. This prepurified extract was separated by a multistep chromatographic method, applying RPCC twice. The purification was based on the differences in sample load throughout the chromatographic process. In the first RPCC separation, the column was highly loaded and a multistep gradient was used, but each gradient step was large. Two of the four fractions gained (I/B and I/C) increased the mRNA level of Slap. The difference between the effects of the two fractions was non-significant (Fig. 7). 


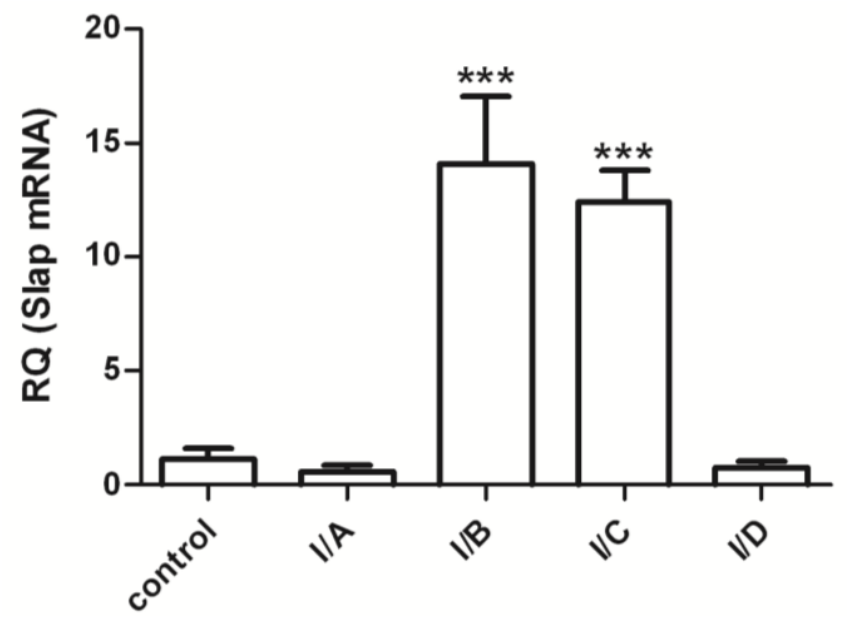

Figure 7. Bioactivity-guided fractionation 1. The 40\%, $60 \%$ and $80 \%$ aqueous $\mathrm{MeOH}(\mathrm{I} / \mathrm{B})$ and $100 \% \mathrm{MeOH}$ (I/C) fractions increased the relative quantity of Slap in the RT-PCR assay. Further separation of fraction I/B resulted in loss of the effect (result not shown).

I/A: $20 \%$ aqueous $\mathrm{MeOH}$ fraction; I/B: $40 \%, 60 \%$ and $80 \%$ aqueous $\mathrm{MeOH}$ fraction; I/C: $100 \% \mathrm{MeOH}$ fraction; I/D: dichloromethane fraction; $* * * \mathrm{p}<0.001$; RQ: relative quantity

Further fractionation was performed on fractions $\mathrm{I} / \mathrm{B}$ and $\mathrm{I} / \mathrm{C}$, but the further separation of fraction I/B resulted in a total loss of the androgenic effect (results not shown).

In the second RPCC for fraction I/C, the ratio of load to sorbent was high (1:20) and the elution gradient steps were smaller. After each column chromatography step, the fractions with the same compositions were combined. One of the six fractions gained (II/E) increased the mRNA level of Slap (Fig. 8).

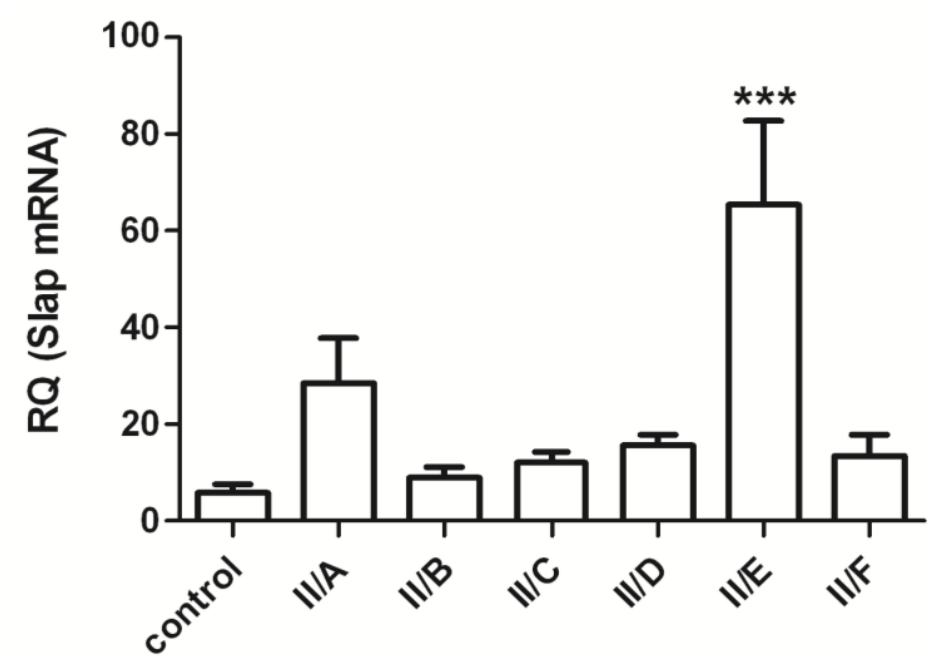

Figure 8. Bioactivity-guided fractionation 2. From among the 4 fractions of $75 \%$ aqueous acetone, the last fraction (II/E) increased the relative quantity of Slap in the RT-PCR assay. II/A: 70\% aqueous acetone fraction; II/B, II/C, II/D and II/E: 75\% aqueous acetone fractions; II/F: 100\% aqueous acetone fraction; *** p<0.001; RQ: relative quantity 


\subsubsection{Identification of the androgenic compound(s) of raw drone milk}

Fraction II/E was subjected to TLC, mass spectral (MS) and NMR analyses. In order to characterize the biologically active components fraction II/E was subjected to GC-HRMS and NMR spectroscopic investigation. The GC chromatogram indicated the presence of two main components in the sample (RT 9.03 and $9.73 \mathrm{~min}$ ). The accurate mass values determined for these components were 270.0258 and 296.2707 , corresponding to the elemental compositions of $\mathrm{C}_{17} \mathrm{H}_{34} \mathrm{O}_{2}$ (methyl palmitate; MP) and $\mathrm{C}_{19} \mathrm{H}_{36} \mathrm{O}_{2}$ (methyl oleate; MO), respectively. A database and literature search (Hallgren et al., 1959; Ryhage \& Stenhagen, 1959) suggested (in accordance with the fragmentation characteristics) that the two main components were the well-known fatty acid methyl esters, MP and MO. These structural suggestions were confirmed by comparing the ${ }^{1} \mathrm{H}$ and ${ }^{13} \mathrm{C}$ NMR data with those available in the literature (Gunstone \& Ismail, 1967; Couperus et al., 1978), and by comparing the GC-HRMS chromatograms and spectra of the collected sample with those measured on the purchased compounds. These results unambiguously identified the two components present in the biologically active fraction II/E as MP and MO (Fig. 9).

A.

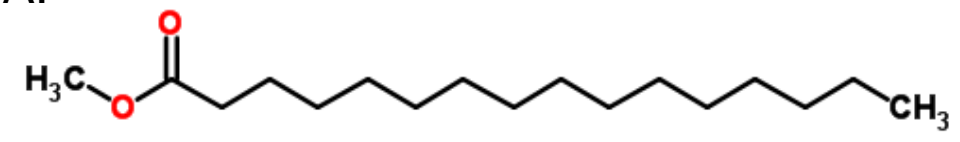

B.

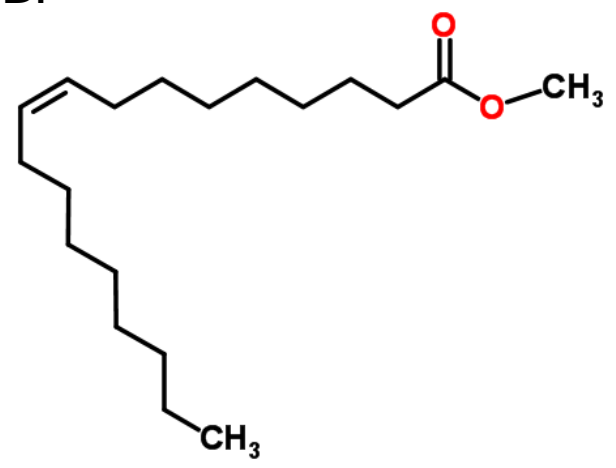

Figure 9. Structure of methyl palmitate (A) and methyl oleate (B) (ChemSpider database).

After the isolation of MO and MP from fraction II/E, we investigated their contributions to the androgenic effect with our simplified Hershberger assay and plasma testosterone assay. MO, MP and their specific combination (molar ratio: 4:3=MO:MP) were administered in doses of 2.5, 25 and $250 \mu \mathrm{g} / \mathrm{kg}$. The $25 \mu \mathrm{g} / \mathrm{kg}$ dose of MP and the highest dose ( $250 \mu \mathrm{g} / \mathrm{kg})$ of the MO and MP combination increased the weights of androgen-sensitive organs (except the prostate tissue). These androgenic effects, similarly to those of raw DM, were flutamidesensitive (Fig 10). The results of ineffective doses are not shown. 
A.

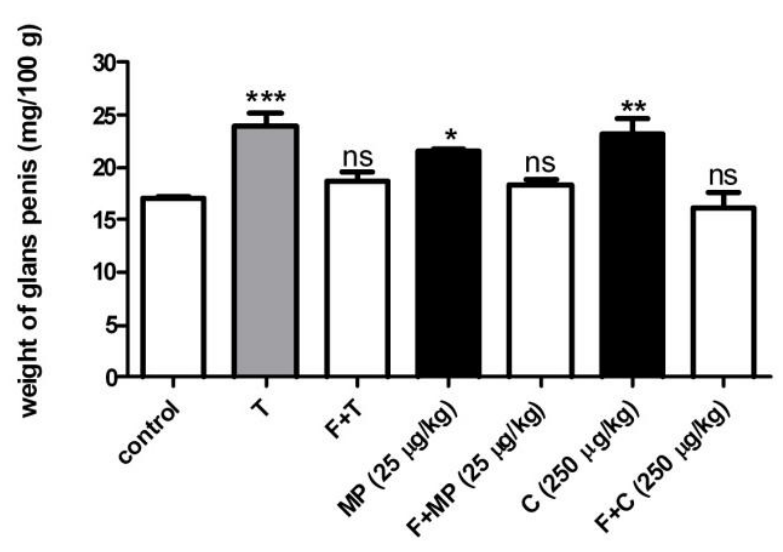

C.

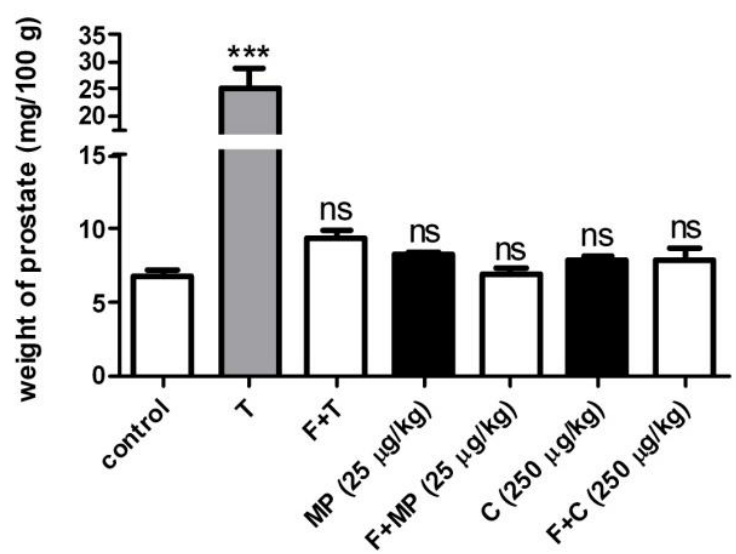

B.

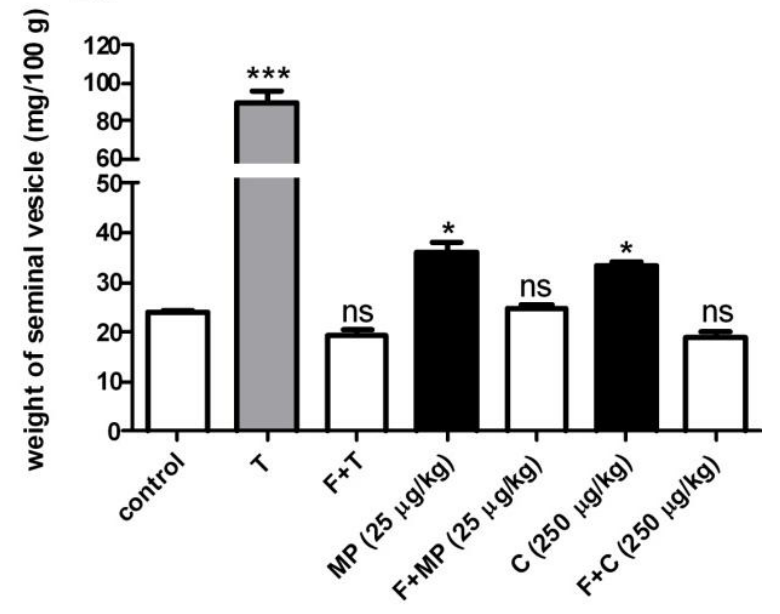

D.

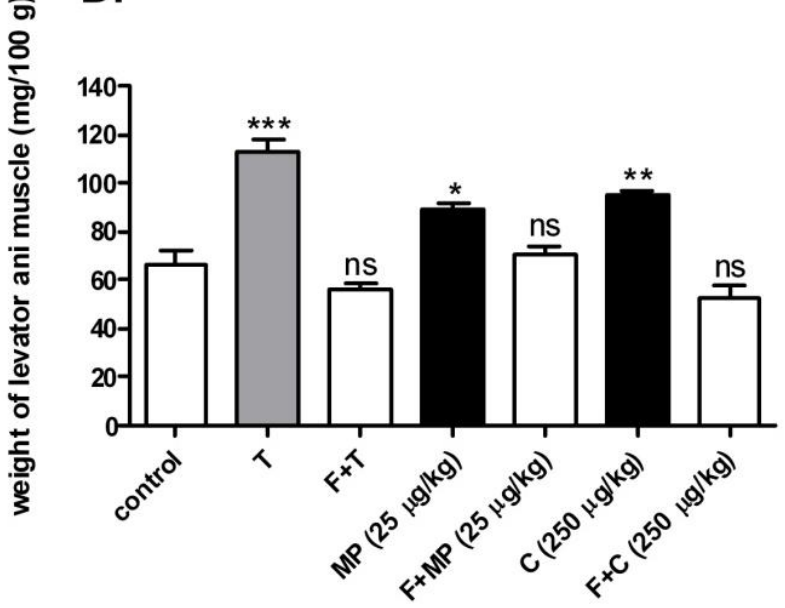

Figure 10. Changes in weights of androgen-sensitive organs following treatment with a $25 \mu \mathrm{g} / \mathrm{kg}$ (middle) dose of methyl palmitate (MP) and a $250 \mu \mathrm{g} / \mathrm{kg}$ (high) dose of the combination of methyl oleate and methyl palmitate $(\mathbf{C})$ in castrated male rats. These doses increased the relative weights ( $\mathrm{mg} / 100 \mathrm{~g}$ body weight) of the glans penis (A), seminal vesicle (B) and levator ani muscle (D). These effects were flutamide (F)-sensitive. Similarly to the crude drone milk, the compounds had no effect on the prostate $(\mathbf{C})$. Testosterone (T) was used as positive control. *p<0.05; ** $\mathrm{p}<0.01 ; * * * \mathrm{p}<0.001$; ns: not significant

The plasma testosterone level was not affected by either MO or MP in any of the applied doses. In contrast, when the combination was applied in the highest dose, an increase in plasma testosterone level was detected (Fig. 11). 


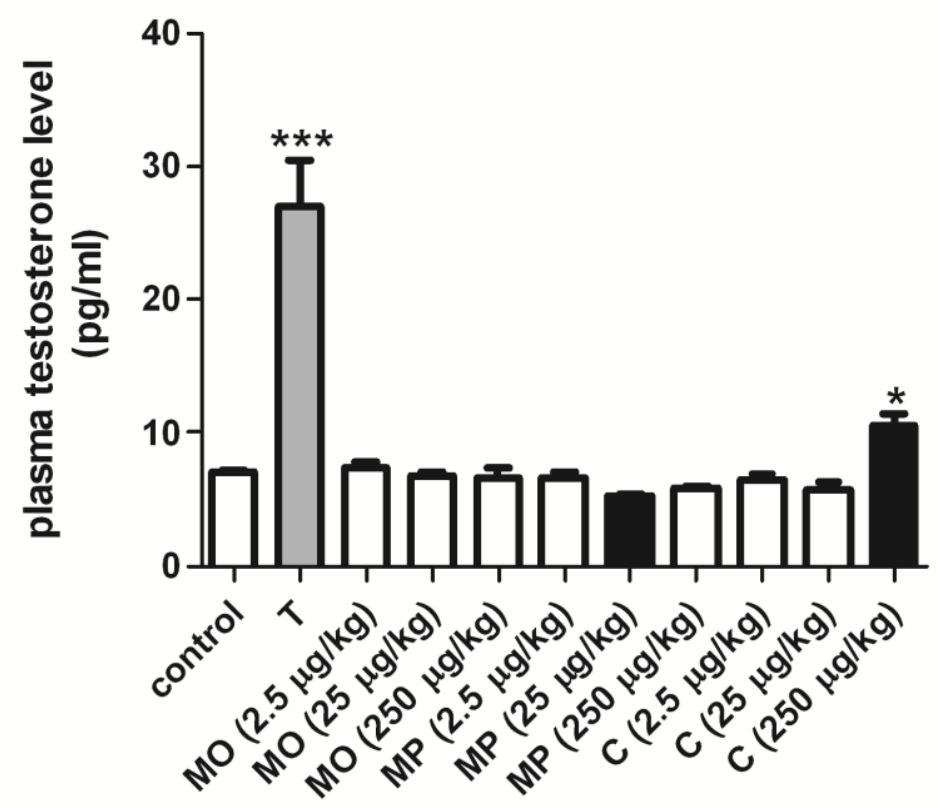

Figure 11. The effects of methyl oleate (MO), methyl palmitate (MP) and their combination (C) on the plasma testosterone levels in castrated male rats. The $250 \mu \mathrm{g} / \mathrm{kg}$ (high) dose of the combination increased the plasma testosterone level. This effect was flutamide (F)-sensitive. The $25 \mu \mathrm{g} / \mathrm{kg}$ (androgenic) dose of methyl palmitate had no effect on the plasma testosterone level. Testosterone (T) was used as positive control. *p $<0.05$; $* * * \mathrm{p}<0.001$

\subsection{Estrogenic effect of drone milk}

\subsubsection{In vivo estrogenic effect of crude drone milk}

The estrogenic activity of raw DM was examined by means of uterotrophic assays. The adequacy of the model in our laboratory was proved by treatment with $17 \beta$-estradiol valerate $\left(E_{2}\right) . E_{2}$ increased the relative weight of the uteri and this activity was diminished by the antiestrogenic ICI 182.780 (ICI). The raw DM was able to increase the relative weight of uteri and similarly to that of $E_{2}$ the estrogenic effect of DM was blocked in the presence of ICI. The soy extract also increased the weight of the uteri (Fig. 12). 


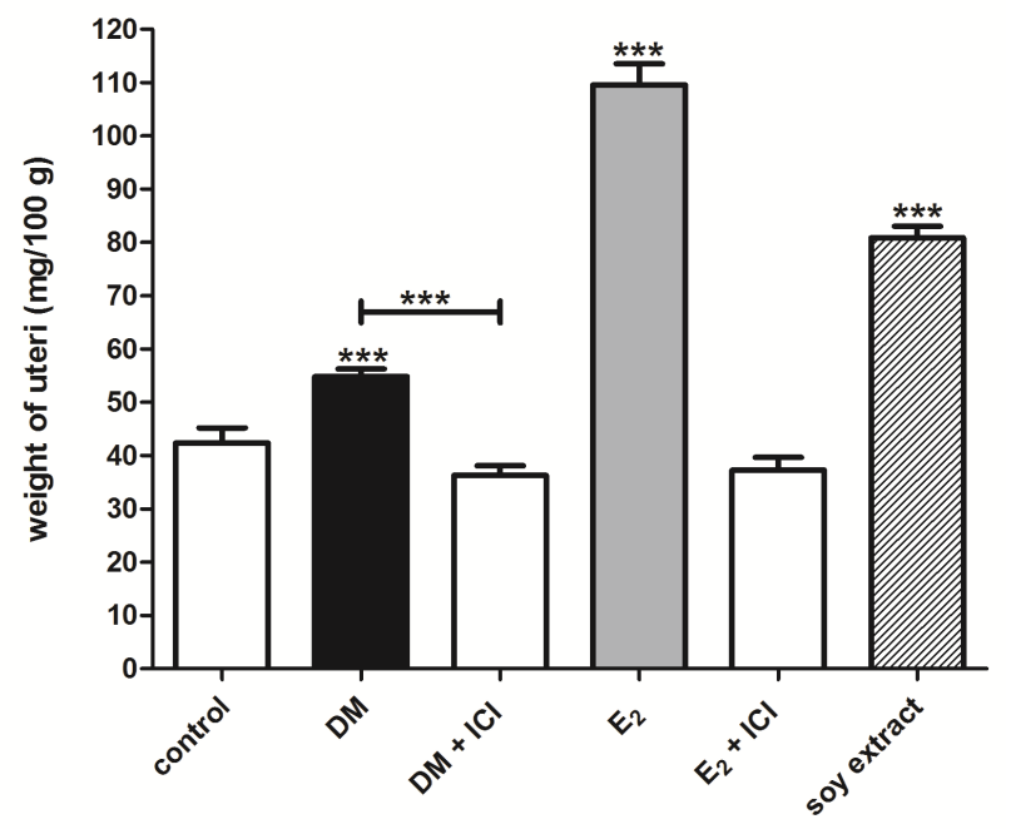

Figure 12. Changes in relative weight of the uteri in immature rats following treatment with crude drone milk $(D M), 17 \beta$-estradiol valerate $\left(\mathbf{E}_{2}\right)$ or soy extract. DM, $E_{2}$ and the soy extract increased the weight of the uteri. These effects were ICI 182.780 (ICI)-sensitive. *** $\mathrm{p}<0.001$; ns: not significant

\subsubsection{Measurements of $\mathrm{C} 3 \mathrm{mRNA}$ and protein in rat uterus}

By means of a real-time PCR technique, we found that DM almost doubled the relative C3 mRNA expression in the uteri. The effect of positive control $\mathrm{E}_{2}$ was also significant (Fig. 13).

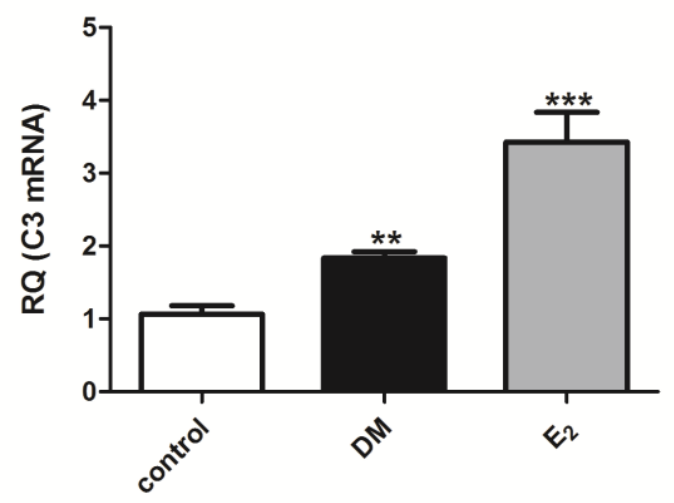

Figure 13. RT-PCR analysis of complement component C3 (C3) mRNA expression in rat uteri. The crude drone milk (DM) increased the mRNA expression of the estrogen-dependent C3 in rat uterus tissue. $*^{*} \mathrm{p}<0.01$; $* * * \mathrm{p}<0.001$

In Western blot measurement DM enhanced the level of $\mathrm{C} 3$ in the uterine tissue, and $\mathrm{E}_{2}$ was also effective (Fig. 14). The gel photo $(\boldsymbol{B})$ reveals that the $\mathrm{C} 3$ protein is split into alpha and 
beta chains during Western blot studies; the densities of both chains were therefore evaluated (A).

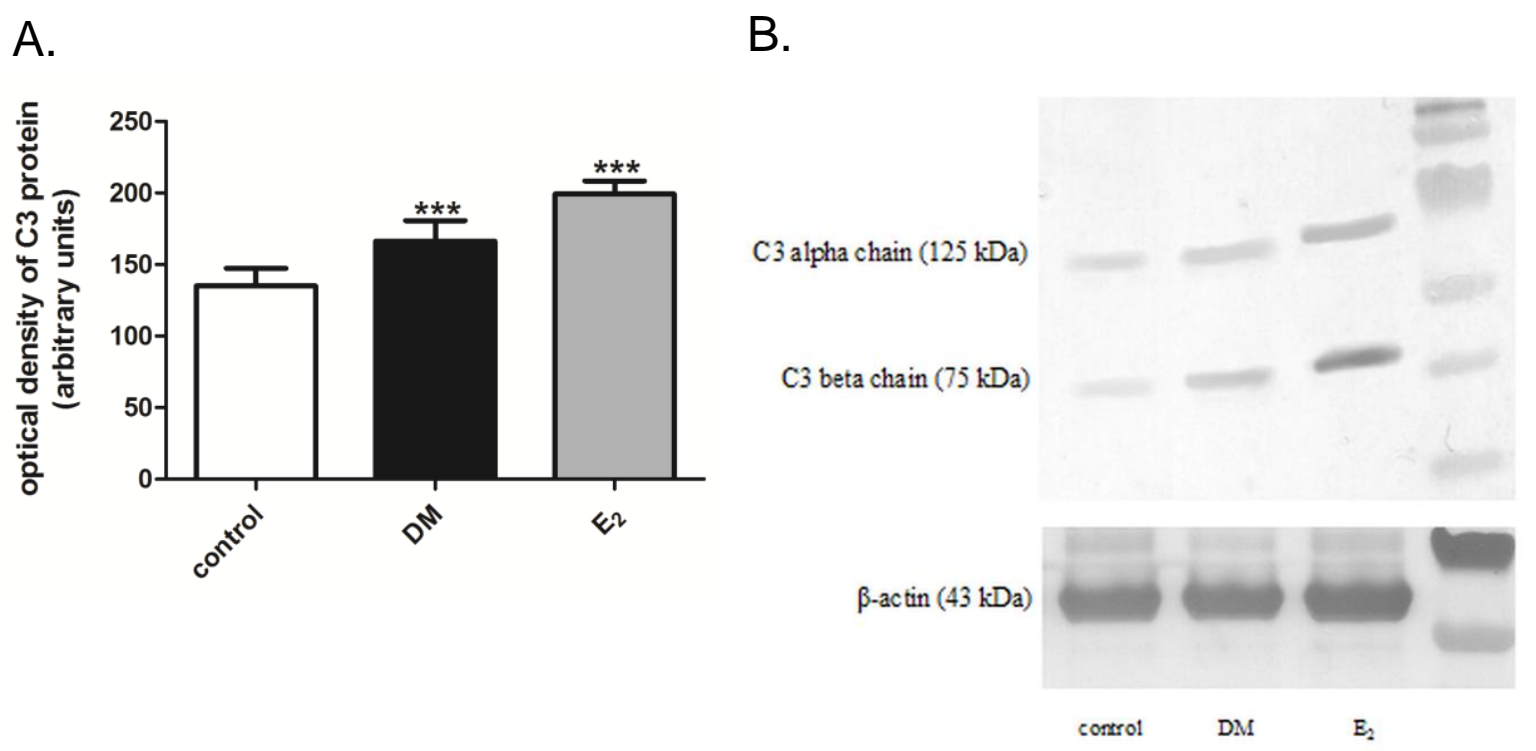

Figure 14. Western blot analysis of complement component $\mathrm{C} 3$ protein in rat uteri. The crude drone milk (DM) increased the expression of the estrogen-dependent $\mathrm{C} 3$ protein in rat uterus tissue (A).The $\mathrm{C} 3$ alpha and beta chains were detected on gel (B). ${ }^{* * *} \mathrm{p}<0.001$

\subsubsection{Bioactivity-guided fractionation}

The crude DM was diluted with water and extracted with petroleum ether in order to remove apolar contaminants. The pre-purified extract was subjected to repeated RP CC. After the first separation, the fractions with the same compositions were combined and tested by uterotrophic assay (Fig. 15).

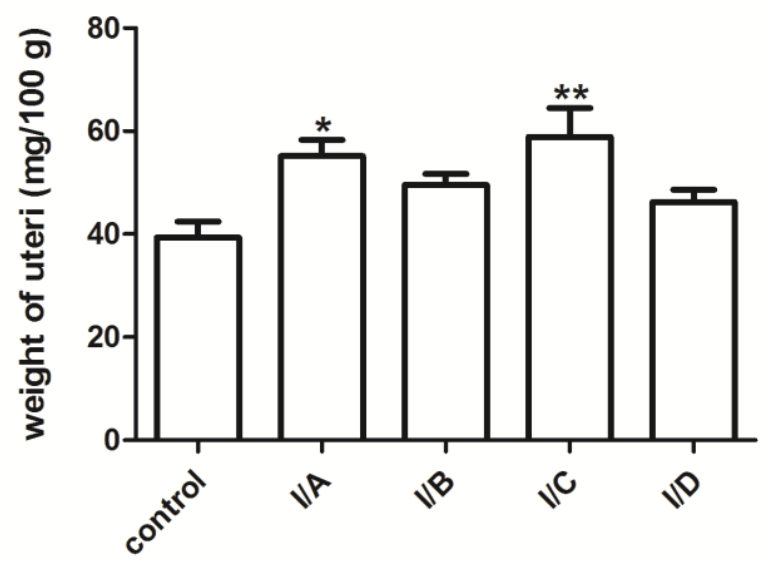

Figure 15. Bioactivity-guided fractionation 1. The $20 \%$ aqueous $\mathrm{MeOH}(\mathrm{I} / \mathrm{A})$ and pure $\mathrm{MeOH}(\mathrm{I} / \mathrm{C})$ fractions increased the relative weight of the uteri. I/A: $20 \%$ aqueous $\mathrm{MeOH}$ fraction; I/B: $40 \%, 60 \%$ and $80 \%$ aqueous $\mathrm{MeOH}$ fraction; I/C: $100 \% \mathrm{MeOH}$ fraction; I/D: dichloromethane fraction; $* \mathrm{p}<0.05 ; * * \mathrm{p}<0.01$ 
Further separations were done with fraction $\mathrm{I} / \mathrm{C}$, but new fractions were ineffective in uterotrophic assay, therefore we did not continue the investigation of this product. On the basis of the results, the other two fractions (I/A and I/B) were chosen for further separation. As the main constituent of the more active fraction (I/A) was also present in I/B, although the material content of the latter was much lower, these two fractions were combined and purified together by column cromatography (CC). The second CC separation, with the stationary phase in a high (e.g. 20-fold) excess, and elution of the constituents with a multistep gradient, proved to permit rather effective purification. The pharmacological experiments led to four fractions being subjected to further examination by uterotrophic assay (Fig. 16).

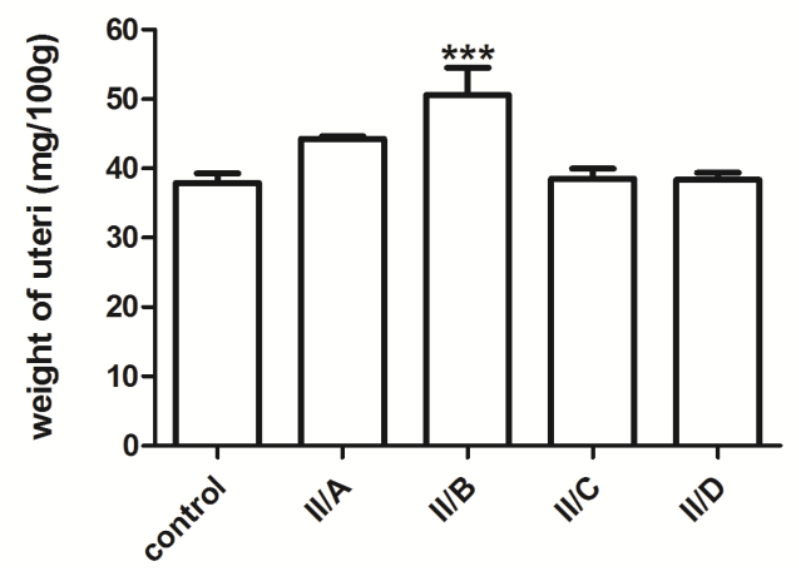

Figure 16. Bioactivity-guided fractionation 2. Only fraction II/B increased the relative organ weight of the uteri. From this fraction, the effective compound, E-dec-2-enedioic acid, was purified. II/A: 20\% aqueous $\mathrm{MeOH}$ fraction; II/B: 35\% aqueous $\mathrm{MeOH}$ fraction; II/C: 70\% aqueous $\mathrm{MeOH}$ fraction; II/D: $75 \%$ aqueous $\mathrm{MeOH}$ fraction; *** $\mathrm{p}<0.001$

\subsubsection{Identification of the estrogenic compound(s) of raw drone milk}

The most active fraction II/B was purified by preparative reverse-phase thin-layer chromatography (TLC). The fraction obtained (fraction III/A) was subjected to TLC, MS and NMR analyses.

This fraction was multicomponent, but one of the main components could be identified by HR-ESI-MS, ${ }^{1}$ H-Presat and 2D-homo- (ZTOCSY) and heteronuclear correlation (GHSQCAD, GHMBCAD) data. In the HR-ESI-MS spectrum, the sodium adduct of the molecular ion was detected at $223 \mathrm{~m} / \mathrm{z}$. The accurate mass value (223.09401) of this ion corresponded with an accuracy of $0.3 \mathrm{ppm}$ to an elemental composition $\mathrm{C}_{10} \mathrm{H}_{16} \mathrm{O}_{4} \mathrm{Na}$. Analysis of the ${ }^{1} \mathrm{H}$ NMR spectrum indicated the presence of a trans double bond, as evidenced by two 
doublets of triplets at $5.80(\mathrm{H}-2, \mathrm{~J}=15.5$ and $1.5 \mathrm{~Hz})$ and $6.92 \mathrm{ppm}(\mathrm{H}-3, \mathrm{~J}=15.5$ and $6.9 \mathrm{~Hz})$. The correlations of the methylene and olefinic protons observed in the one- and twodimensional ZTOCSY spectra permitted the complete ${ }^{1} \mathrm{H}$ NMR assignment of the identified compound. The HSQC and HMBC spectra suggested the presence of two carboxylic groups, bound to C-2 and C-9 (H-2 and H-3 correlate with a carbon at 170.6 ppm, (C-1), and H-8 and H-9 correlate with a carbon at $177.8 \mathrm{ppm}$ (C-10)). Structure of this compound, the E-dec-2enedioic acid accords with the determined elemental composition of the main component (Fig. 17).

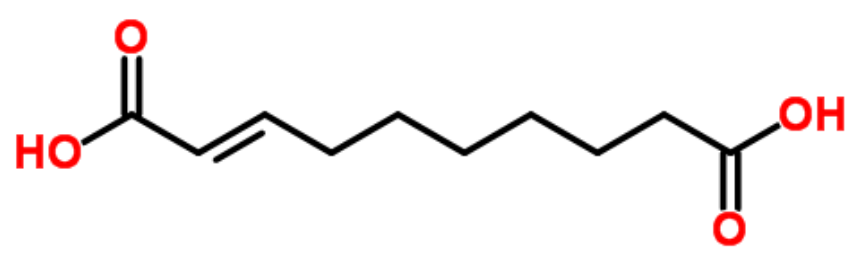

Figure 17. Structure and carbon atom numbering of E-dec-2-enedioic acid (ChemSpider database).

\subsection{Gestagenic effect of drone milk}

\subsubsection{In vivo gestagenic effect of crude drone milk}

The gestagenic activity of crude DM was investigated by means of pregnancy maintenance assays. The $\mathrm{E}_{2}$ treatment (as negative control) led to the complete loss of pregnancy in ovariectomized pregnant rats, but the combination of $\mathrm{E}_{2}$ and $\mathrm{DM}$ resulted in the survival of $17.4 \%$ of the fetuses. Although the number of surviving fetuses was increased, this effect was not statistically significant. The combination of $\mathrm{E}_{2}$ and $\mathrm{P}$ (as positive control) displayed a well-defined pregnancy-maintaining effect, with a fetus survival rate of $98.8 \%$ (Fig. 18).

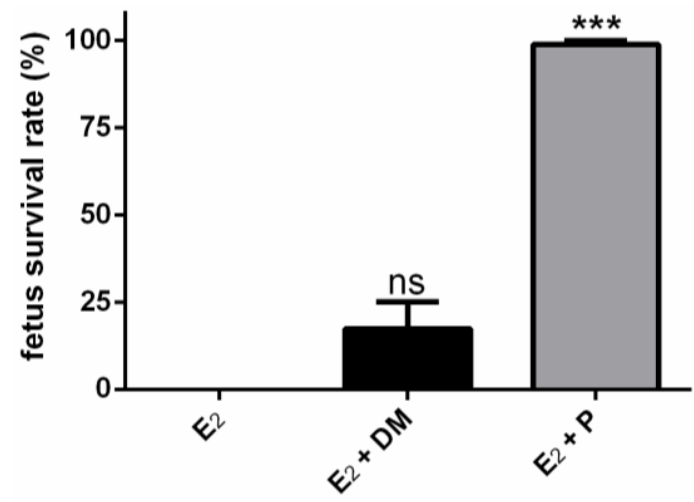

Figure 18. Changes in fetus survival following treatment with 17ß-estradiol valerate $\left(E_{2}\right)$, with a combination of $E_{2}$ and drone milk (DM), or with a combination of $E_{2}$ and progesterone (P). The DM treatment kept $17.4 \%$ of the fetuses alive. $* * * \mathrm{p}<0.001$; ns: not significant 


\subsubsection{Measurements of CRLR mRNA and protein in rat uterus}

The crude DM increased the expression of CRLR mRNA in the rat uterus, similarly to P. Western blot measurements yielded similar results, DM treatment increased the level of CRLR protein. The representative gel photo shows the change in CRLR proteins together with GAPDH (Fig. 19).

A.

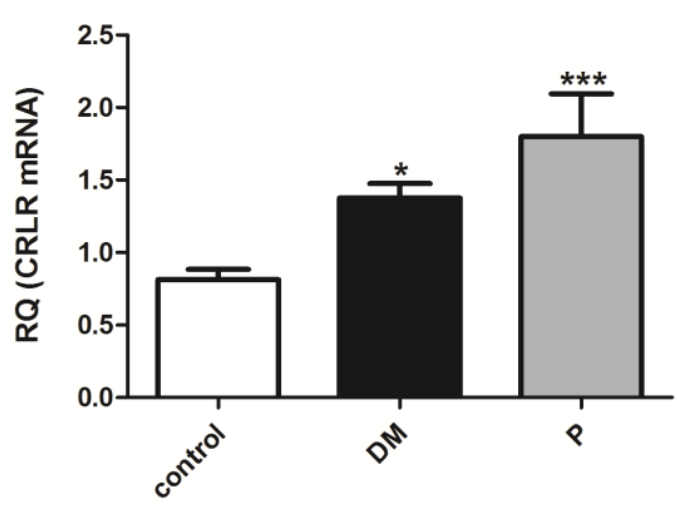

C.
B.

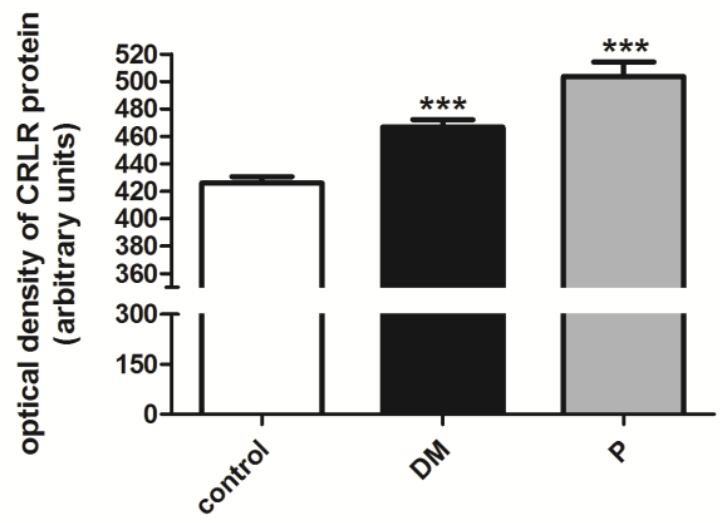

CRLR (60 kDa)

GAPDH (37 kDa)

control DM P

Figure 19. RT-PCR (A) and Western blot (B) analysis of CRLR mRNA and protein. Raw drone milk (DM) increased the mRNA (A) and protein (B) expression of the gestagen-dependent CRLR in rat uterus tissue. The representative gel photo $(\mathbf{C})$ shows the changes in CRLR proteins after the treatments. $* \mathrm{p}<0.05 ; * * * \mathrm{p}<0.001$; RQ: relative quantity

\subsubsection{Measurement of the gestagenic efficacy of drone milk}

In our next experiment, we made use of the weak gestagenic compound SP. SP was used alone and in combination with DM. SP alone did not increase the expression of CRLR mRNA, but its combination with DM caused a marked increase in CRLR mRNA (Fig. 20). 


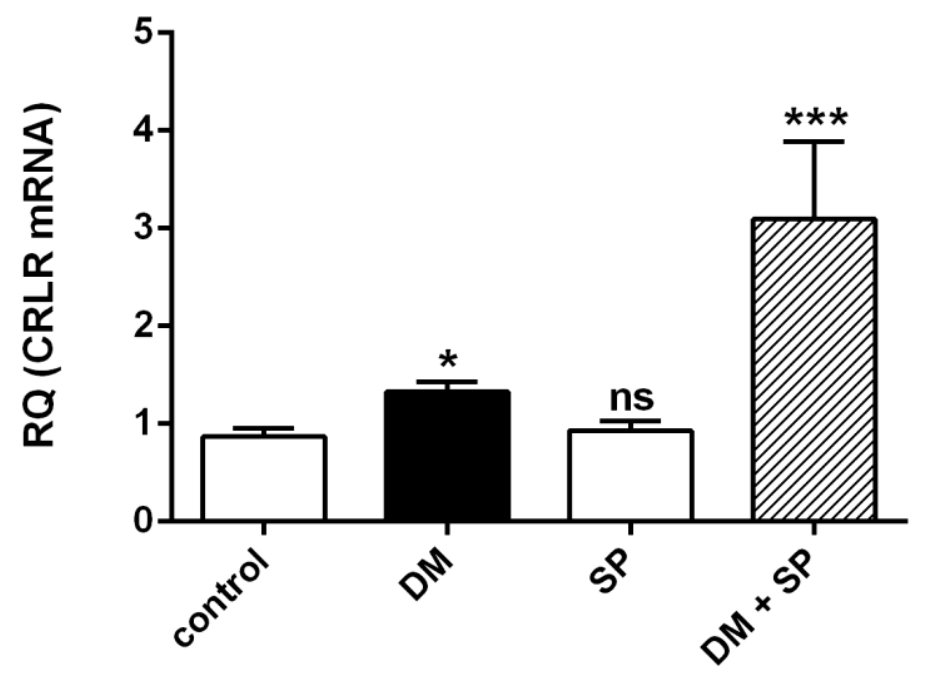

Figure 20. Effects of spironolactone (SP) and its combination with crude drone milk (DM) on CRLR mRNA expression. SP alone did not cause any changes in CRLR mRNA expression, but the combination of SP and DM was more effective than DM itself. *p<0.05; *** $\mathrm{p}<0.001$; RQ: relative quantity

The combination of DM and SP kept $21.4 \%$ of the fetuses alive, and (unlike the action of DM alone) this effect was significant (Fig. 21).

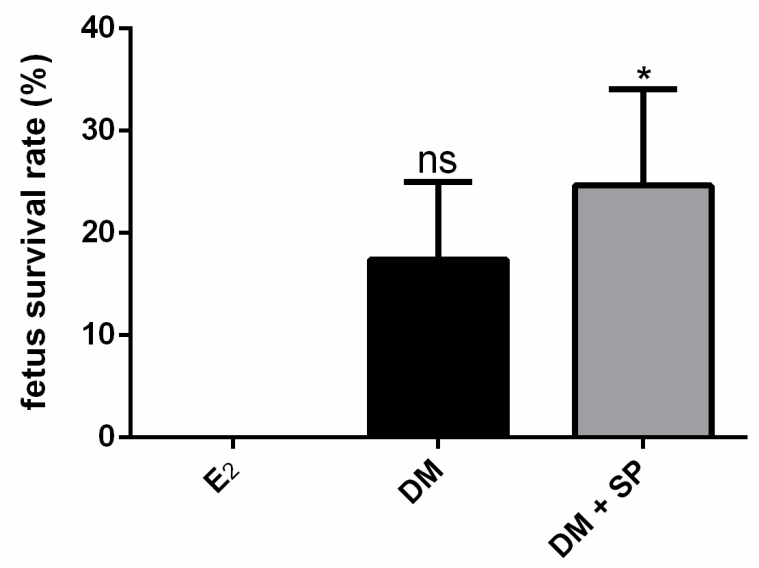

Figure 21. Changes in fetal survival rate following treatment with crude drone milk (DM), or with a combination of DM and spironolactone (SP). The combination kept $21.4 \%$ of the fetuses alive. $* \mathrm{p}<0.05$; ns: not significant 


\section{Discussion}

\subsection{Evidence of an androgenic effect of drone milk}

DM is a lesser-known honeybee product; it is a purified extract of drone brood without larvae and pupae and the main food of drone bees and larvae. DM and frozen drone larvae are used in folk medicine and are available as a dietary supplement and an aphrodisiac (Frozen drone larvae royal jelly®, Apidom Ltd, Russian Federation; Apilarnil Potent ${ }^{\circledR}$, S.C. Biofarm S.A., Bucuresti, Romania). Since the folk medicine uses drone brood to treat sexual problems in both genders, we hypothesized that DM may have some hormonal effects, too. Therefore we searched for both male and female hormonal effect and the active components of DM.

This study first proved the androgenic effect of raw DM by its action to increase weight of the androgen-sensitive organs, except the prostate, in rats. Unlike testosterone, DM did not increase the body weights of the rats, suggesting that the material does not have pronounced anabolic activity. Apart from steroid hormones, no androgenic animal products are known in the scientific literature. The haemolymph of insects contain ecdysteroids, which demonstrate varied pharmacological effects in mammals. In contrast with DM, these compounds have anabolic effects (Dinan \& Lafont, 2006; Toth et al., 2008), but their androgenic effect is absent.

Surprisingly, the raw DM increased not only weight of the androgen-sensitive organs but also the plasma testosterone level in castrated rats. This result suggests that DM may induce the non-testicular synthesis of testosterone in rats. The antiandrogenic flutamide reduced the plasma testosterone level-increasing effect of DM. Flutamide is known to reduce the synthesis of androgens by inhibiting CYP17A1, which is responsible for dehydroepiandrosterone (DHEA) synthesis, and/or by increasing their metabolism (Moghetti et al., 2000). The latter can explain the testosterone plasma level-reducing effect of flutamide followed by testosterone treatment. CYP17, the key enzyme of androgenesis is expressed predominantly in the gonads and is absent from the adrenal glands in rats (Brock \& Waterman, 1999). However, it displays relatively high activity in the gastrointestinal tract and kidneys of rats. DHEA is transformed to testosterone by $3 \beta$ - and $17 \beta$-hydroxysteroid dehydrogenases (HSD), but these enzymes are significantly active in the testicular and renal tissues (Dalla Valle et al., 1995; Dalla Valle et al., 2004). We therefore presume that DM may induce testosterone synthesis via the enzymes CYP17 and HSD in the renal tissues of castrated rats. 
We set out to prove the androgenic effect of DM at a molecular level, targeting mainly the androgen-sensitive prostatic proteins in castrated rats. Although the increase in weight of the prostatic tissue response to DM was not significant, we attempted to determine whether the level of androgen-sensitive SLAP was altered or not by DM treatment. Both the mRNA and protein expression of SLAP proved to be increased in the rat prostate, which means that, in spite of the non-significant prostate weight-increasing effect of DM, the molecular consequences of its androgenic effect are detectable through the increase in prostatic SLAP level (Nishi et al., 2008). This method was therefore used for further evaluation of the androgenic action of DM fractions.

Bioactivity-guided fractionation was performed to identify the compounds in DM responsible for its androgenic effect. Although we detected two effective fractions (I/B and I/C) after the first fractionation, the effect of fraction $\mathrm{I} / \mathrm{B}$ was lost during the second fractionation. We therefore had to focus on the separation products of fraction I/C.

NMR and MS measurements after the second fractionation revealed MP and MO in the last active fraction (II/E) of the raw DM. Although MO alone had no effect on androgen-sensitive organs, MP (similarly to raw DM) increased the weights of the androgen-sensitive organs (except the prostate) and these effects were flutamide-sensitive. Palmitate is known to play a role in steroidogenesis: it is able to increase the DHEA level through its CYP17 activity (Bellanger et al., 2012). A fatty acid infusion has been reported to elevate human androgen production in both sexes (Mai et al., 2006; Mai et al., 2008). MP was proved to inhibit carrageenan-induced paw oedema by reducing the prostaglandin E2 level (Saeed et al., 2012), an effect which might indicate a steroidogenesis-inducing property. Since DHEA alone has weak androgenic effect, the putative DHEA-elevating effect of MP may explain in part the response of androgen-sensitive organs. The androgenic dose $(25 \mu \mathrm{g} / \mathrm{kg})$ of MP alone did not alter the plasma testosterone level, but its combination with MO in high dose exhibited plasma testosterone-increasing effect, similarly to the action of raw DM. It is known that oleic acid has a weak 5- $\alpha$-reductase inhibitory effect, preventing testosterone conversion to dihydrotestosterone, whereas the esterified analogues of oleic acid (like MO) are ineffective in this respect (Liu et al., 2009). As yet we have no explanation as to why the combination of MP and MO increases the plasma testosterone level in rat. Nevertheless, we have clearly shown that these two compounds have a major role in the main androgenic action of DM. Further studies are required to clarify the androgenic mechanisms of action of MO and MP. 


\subsection{Evidence of an estrogenic effect of drone milk}

Since DM is produced by the worker bees that also prepare RJ, which contains special fatty acids with estrogenic activity, furthermore, DM and drone brood are used in both genders to treat sexual problems, we would like to determine the putative estrogenic effect of crude DM. The raw DM was able to increase the relative organ weights of uteri in immature female rats and this effect was estrogenic antagonist (ICI 182.780) sensitive similarly to the action of $E_{2}$. This result indicates that the raw DM undoubtedly has an estrogenic activity. Although the extent of the weight-increasing effect of DM was moderate as compared with those of soy extract or $\mathrm{E}_{2}$, its estrogenic activity was still noteworthy, as the DM was unpurified material. Besides the uterotrophic assay, we sought molecular markers with which to confirm the estrogenic effect of DM. C3 expression has been reported to be a molecular marker of estrogenic activity (Diel et al., 2000; Lundeen et al., 2001). The raise in the level of the mRNA and protein expression of C3 supports the results of uterotrophic assay. The changes in the uterine level of $\mathrm{C} 3$ protein are other evidences for the estrogenic effect of raw DM.

Similarly to the androgenic effect, bioactivity-guided fractionations were performed to identify the estrogenic compounds in raw DM. Through a three-step procedure we gained a fraction and identified the structure of one main compound. This fraction was different from the androgenic fraction (Fig. 22).

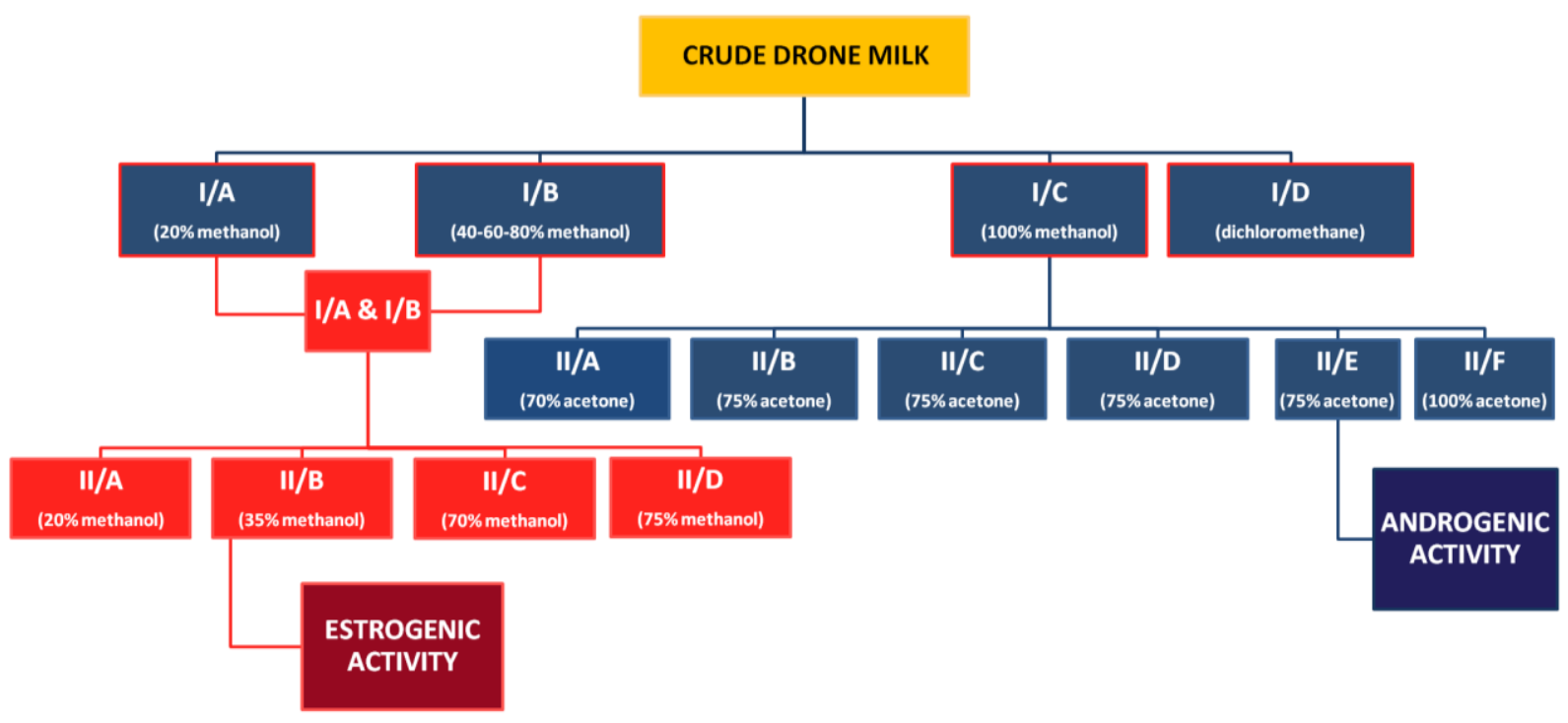

Figure 22. Procedures of bioactivity-guided fractionations.

: fractionation for uterotrophic assay

: fractionation for RT-PCR measurement of Slap 
By HRMS and NMR data the main component in fraction III/A is E-dec-2-enedioic acid, which is very similar to estrogenic fatty acids isolated from RJ. These fatty acids from RJ exhibit weak ER binding activity and bind preferentially to ER $\beta$, which shows moderate expression in rat uterus comparing with ER $\alpha$ (Kuiper et al., 1997). Other estrogenic isoflavonoids, such as genistein, which also exhibits higher affinity to ER $\beta$ than $\mathrm{ER} \alpha$, show prostate cancer risk reducing effect (McCarty, 2006). Genistein is able to inhibit estrogen-induced proliferation (Liu et al., 2002) and down-regulate androgen receptor expression (Bektic et al., 2004) mediated by ER $\beta$. Because of the structural similarity, the identified E-dec-2-enedioic acid supposedly binds to the ER, but further investigations are required to determine which ER subtype is responsible for the estrogenic effect of DM. The molecule is known in scientific literature, because it was found as a major mandibular gland component in queen and worker dwarf honey bees (Keeling et al., 2000), but it has not been found in honey bee products. The biosynthesis of this compound and other similar bee mandibular pheromones and fatty acids are also known (Plettner et al., 1998).

\subsection{Evidence of a gestagenic effect of drone milk}

There have been literature reports that certain honey bee products exert a gestagenic effect besides estrogenic activity. Kridli \& Al-Khetib (2006) described that RJ with an unambiguous estrogenic effect elevated the plasma $\mathrm{P}$ level in pregnant sheep. We therefore set out to determine whether raw DM is capable of such a gestagenic effect.

Crude DM proved to enhance the fetal survival rate in the pregnancy maintenance assay. Although this effect was not significant, it did suggest some weak gestagen-like activity. To confirm this putative gestagenic effect, molecular techniques were used. It is known that the mRNA level of CRLR is increased by gestagens in ovariectomized rats or during pregnancy. Estrogens can also influence the expression of CRLR: they decrease this expression, but their joint effect shifts from estrogenic activity to gestagenic activity. This means that a combination of estrogen and P will increase the CRLR expression (Thota et al., 2003). RTPCR measurements showed that crude DM, similarly to P, increased the mRNA expression of CRLR. The Western blot investigations also confirmed the results of RT-PCR measurements; raw DM enhanced the protein level of CRLR in rat uterine tissues. During RT-PCR experiments, we found that, in contrast with DM the weak gestagen SP alone, did not increase the mRNA expression of CRLR, but its combination with DM gave rise to a significantly 
higher mRNA level of CRLR. The combination exhibited a threefold higher gestagenic effect than that of crude DM.

Our results clearly show that crude DM elicits a gestagenic effect when it is combined with another weak gestagenic compound, but the mechanism of action is still unknown. The gestagenic compound(s) in DM probably enhance(s) the sexual hormone levels and/or has/have a direct hormonal effect. Another possible explanation is that the identified androgenic or estrogenic compounds in DM may exert a weak gestagenic effect, too. 


\section{Conclusions}

We found that the hitherto unknown DM exhibits significant sexual hormonal effects in both male and female rats. DM displays marked androgenic activity in castrated male rats. We identified the compounds MP and MO which are responsible for its androgenic effect. The exact mechanisms of action of MP and MO are still unknown, but reports in the scientific literature suggest that they are involved in steroidogenesis. Male infertility is an emerging health problem; it is currently responsible for approximately $20 \%$ of all human infertility cases (O'Flynn O'Brien et al., 2010). The fact that crude DM or MP or/and MO treatments are able to increase the weights of androgen-sensitive organs without exerting an accompanying anabolic effect may project a new, natural mode for the therapy of fertility problems in men.

DM clearly shows an estrogenic effect in female rats. E-dec-2-enedioic acid, an estrogenic compounds isolated from crude DM, exhibits structural similarity to the estrogenic compounds of RJ, which are able to bind to the ER. In view of the structural similarity, E-dec2-enedioic acid presumably likewise binds to the ER. The estrogenic activity of DM justifies its use in folk medicine and may lead to new possibilities for its use in estrogen-deficient conditions in women, similarly to RJ.

The identified compounds with hormonal effects (MP, MO and E-dec-2-enedioic acid) differ considerably from the well-known ecdysteroids of insects. Although both DM compounds and ecdysteroids are isolated from insects and exert pharmacological effects on mammals, the DM compounds have non-steroidal structures and well-defined androgenic or estrogenic activities without any anabolic effect.

Raw DM elicits not only androgenic and estrogenic activities, but also a weak gestagenic effect, which becomes relevant in combination with another weak gestagen. The mechanism of this action and the gestagenic compound(s) of DM are still unknown, but the identified androgenic or estrogenic compounds of DM may be responsible for this weak gestagenic activity. 


\section{References}

Allan GM, Arroll B: Prevention and treatment of the common cold: making sense of the evidence. CMAJ 2014; 186:190-199.

Altan O, Yücel B, Açikgöz Z, Seremet C, Kösoğlu M, Turgan N, Ozgönül AM: Apilarnil reduces fear and advances sexual development in male broilers but has no effect on growth. Br Poult Sci 2013; 54:355-361.

de Andrade E, de Mesquita AA, Claro Jde A, de Andrade PM, Ortiz V, Paranhos M, Srougi M: Study of the efficacy of Korean Red Ginseng in the treatment of erectile dysfunction. Asian J Androl 2007; 9:241-244.

Arkaravichien W, Kendle KE: Critical progesterone requirement for maintenance of pregnancy in ovariectomized rats. J Reprod Fertil 1990; 90:63-70.

Aso T: Equol improves menopausal symptoms in Japanese women. J Nutr 2010; 140:1386S1389S.

Bathori M, Toth N, Hunyadi A, Marki A, Zador, E:. Phytoecdysteroids and anabolicandrogenic steroids--structure and effects on humans. Curr Med Chem 2008; 15:75-91.

Bektic J, Berger AP, Pfeil K, Dobler G, Bartsch G, Klocker H: Androgen receptor regulation by physiological concentrations of the isoflavonoid genistein in androgen-dependent LNCaP cells is mediated by estrogen receptor beta. Eur Uro 2004; 45:245-251.

Bellanger S, Battista MC, Fink GD, Baillargeon JP: Saturated fatty acid exposure induces androgen overproduction in bovine adrenal cells. Steroids 2012; 77:347-353.

Brock BJ, Waterman MR: Biochemical differences between rat and human cytochrome P450c17 support the different steroidogenic needs of these two species. Biochemistry 1999; 38:1598-1606.

Bogdanov S: The Bee Products: The Wonders of the Bee Hexagon. 2011.

Chhatre S, Nesari T, Somani G, Kanchan D, Sathaye S: Phytopharmacological overview of Tribulus terrestris. Pharmacogn Rev 2014; 8:45-51.

Choi YD, Rha KH, Choi HK: In vitro and in vivo experimental effect of Korean red ginseng on erection. J Urol 1999; 162:1508-1511. 
Cho KS, Park CW, Kim CK, Jeon HY, Kim WG, Lee SJ, Kim YM, Lee JY, Choi YD: Effects of Korean ginseng berry extract (GB0710) on penile erection: evidence from in vitro and in vivo studies. Asian J Androl 2013; 15:503-507.

Couperus PA, Clague ADH, van Dongen JPCM: Carbon-13 chemical shifts of some model carboxylic acids and esters. Org Magn Resonance 1978, 11:590-597.

Dalla Valle L, Couet J, Labrie Y, Simard J, Belvedere P, Simontacchi C, Labrie F, Colombo L: Occurrence of cytochrome P450c17 mRNA and dehydroepiandrosterone biosynthesis in the rat gastrointestinal tract. Mol Cell Endocrinol 1995; 111:83-92.

Dalla Valle L, Toffolo V, Vianello S, Belvedere P, Colombo L: Expression of cytochrome $\mathrm{P} 450 \mathrm{c} 17$ and other steroid-converting enzymes in the rat kidney throughout the life-span. $J$ Steroid Biochem Mol Biol 2004; 91:49-58.

Diel P, Schulz T, Smolnikar K, Strunck E, Vollmer G, Michna H: Ability of xeno- and phytoestrogens to modulate expression of estrogen-sensitive genes in rat uterus: estrogenicity profiles and uterotropic activity. J Steroid Biochem Mol Biol 2000; 73:1-10.

Dinan L, Lafont R: Effects and applications of arthropod steroid hormones (ecdysteroids) in mammals. J Endocrinol 2006; 191:1-8.

Edouard MJ, Miao L, Fan GW, Ojong BB, Zhen H, Zhang J, Gao XM, Zhu Y: Yangtonifying traditional Chinese medicinal plants and their potential phytoandrogenic activity. Chin J Nat Med 2014; 12:321-334.

Elger W, Beier S, Pollow K, Garfield R, Shi SQ, Hillisch A: Conception and pharmacodynamic profile of drospirenone. Steroids 2003; 68:891-905.

Estrada-Reyes R, Ortiz-Lopez P, Gutierrez-Ortiz J, Martinez-Mota L:. Turnera diffusa Wild (Turneraceae) recovers sexual behavior in sexually exhausted males. J Ethnopharmacol 2009; 123:423-429.

Freyberger A, Ellinger-Ziegelbauer H, Krotlinger F: Evaluation of the rodent Hershberger bioassay: testing of coded chemicals and supplementary molecular-biological and biochemical investigations. Toxicology 2007; 239:77-88.

Gauthaman K, Adaikan PG, Prasad RN: Aphrodisiac properties of Tribulus Terrestris extract (Protodioscin) in normal and castrated rats. Life Sci 2002; 71:1385-1396.

Gunstone FD, Ismail IA: Fatty acids, part 15. Nuclear magnetic resonance spectra of the CIS octadecenoic acids and of some acetylenic acids. Chem Phys Lipids 1967; 1:337. 
Hallgren B, Ryhage R, Stenhagen E: The mass spectra of methyl oleate, methyl linoleate and methyl linolenate. Acta Chem Scand 1959; 13:845-847.

Hartfelder K, Bitondi MM, Santana WC, Simoes ZL: Ecdysteroid titer and reproduction in queens and workers of the honey bee and of a stingless bee: loss of ecdysteroid function at increasing levels of sociality? Insect Biochem Mol Biol 2002; 32:211-216.

Jang DJ, Lee MS, Shin BC, Lee YC, Ernst E: Red ginseng for treating erectile dysfunction: a systematic review. Br J Clin Pharmacol 2008; 66:444-450.

Kamakura M: Royalactin induces queen differentiation in honeybees. Nature 2011; 473:478483.

Kanno J, Onyon L, Haseman J, Fenner-Crisp P, Ashby J, Owens W: The OECD program to validate the rat uterotrophic bioassay to screen compounds for in vivo estrogenic responses: phase 1. Environ Health Perspect 2001; 109:785-794.

Keeling CI SK, Koeniger N, Koeniger G, Punchihewa RWK: Quantitative analysis of the mandibular gland components of the dwarf honey bee (Apis florea Fabricus). Apidologie 2000; 31:293-299.

Kridli RT, Al-Khetib SS: Reproductive responses in ewes treated with eCG or increasing doses of royal jelly. Anim Reprod Sci 2006; 92:75-85.

Kuiper GG , Carlsson B, Grandien K, Enmark E, Häggblad J, Nilsson S, Gustafsson JA: Comparison of the ligand binding specificity and transcript tissue distribution of estrogen receptors alpha and beta. Endocrinology 1997; 138:836-870.

Liu J, Shimizu K, Kondo R: Anti-androgenic activity of fatty acids. Chem Biodivers 2009; 6:503-512.

Liu MM, Albanese C, Anderson CM, Hilty K, Webb P, Uht RM, Price RH Jr, Pestell RG, Kushner PJ: Opposing action of estrogen receptors alpha and beta on cyclin D1 gene expression. J Biol Chem 2002; 277:24353-24360.

Lundeen SG, Zhang Z, Zhu Y, Carver JM, Winneker RC: Rat uterine complement C3 expression as a model for progesterone receptor modulators: characterization of the new progestin trimegestone. J Steroid Biochem Mol Biol 2001; 78:137-143.

Mai K, Bobbert T, Kullmann V, Andres J, Rochlitz H, Osterhoff M, Weickert MO, Bahr V, Mohlig M, Pfeiffer AF, Diederich S, Spranger J: Free fatty acids increase androgen precursors in vivo. J Clin Endocrinol Metab 2006; 91:1501-1507. 
Mai K, Bobbert T, Reinecke F, Andres J, Maser-Gluth C, Wudy SA, Mohlig M, Weickert MO, Hartmann MF, Schulte HM, Diederich S, Pfeiffer AF, Spranger J: Intravenous lipid and heparin infusion-induced elevation in free fatty acids and triglycerides modifies circulating androgen levels in women: a randomized, controlled trial. J Clin Endocrinol Metab 2008; 93:3900-3906.

Majtan J: Honey: an immunomodulator in wound healing. Wound Repair Regen 2014; 22:187-192.

McCarty MF: Isoflavones made simple - genistein's agonist activity for the beta-type estrogen receptor mediates their health benefits. Med Hypotheses 2006; 66:1093-1114.

Messina M: Soy foods, isoflavones, and the health of postmenopausal women. Am J Clin Nutr 2014; 100:423S-430S.

Mishima S, Suzuki KM, Isohama Y, Kuratsu N, Araki Y, Inoue M, Miyata T: Royal jelly has estrogenic effects in vitro and in vivo. J Ethnopharmacol 2005; 101:215-220.

Moghetti P, Tosi F, Tosti A, Negri C, Misciali C, Perrone F, Caputo M, Muggeo M, Castello $\mathrm{R}$ : Comparison of spironolactone, flutamide, and finasteride efficacy in the treatment of hirsutism: a randomized, double blind, placebo-controlled trial. J Clin Endocrinol Metab 2000; 85:89-94.

Moon HJ, Kang TS, Kim TS, Kang IH, Ki HY, Kim SH, Han SY: OECD validation of phase 3 Hershberger assay in Korea using surgically castrated male rats with coded chemicals. $J$ Appl Toxicol 2009; 29:350-355.

Mutsaers M, van Blitterswijk H, van 't Leven L, Kerkvliet J, van de Waerdt J Bee products: properties, processing and marketing. Wageningen: Agromisa Foundation, In: M. Mutsaers (Ed.), 2005a; pp. 41-42.

Mutsaers M, van Blitterswijk H, van 't Leven L, Kerkvliet J, van de Waerdt J: Bee products: properties, processing and marketing. Wageningen: Agromisa Foundation, In: M. Mutsaers (Ed.), 2005b; pp. 6-11.

Nishi N, Shoji H, Miyanaka H, Nakamura T: Transient up-regulation of a novel member of Spot 14 family in androgen-stimulated rat prostate. Biochim Biophys Acta 2008; 1780:10041009.

O'Flynn O'Brien KL, Varghese AC, Agarwal A: The genetic causes of male factor infertility: a review. Fertil Steril 2010; 93:1-12. 
Ong VY, Tan BK: Novel phytoandrogens and lipidic augmenters from Eucommia ulmoides. BMC Complement Altern Med 2007; 7:3.

Oršolić N: Bee venom in cancer therapy. Cancer Metastasis Rev 2012; 31:173-194.

Paul IM, Beiler J, McMonagle A, Shaffer ML, Duda L, Berlin CM Jr: Effect of honey, dextromethorphan, and no treatment on nocturnal cough and sleep quality for coughing children and their parents. Arch Pediatr Adolesc Med 2007; 161:1140-1146.

Plettner E, Slessor KN, Winston ML: Biosynthesis of mandibular acids in honey bees (Apis mellifera): de novo synthesis, route of fatty acids hydroxylation and caste selective betaoxydation. Insect Biochem 1998; 28:31-42.

Remolina SC, Hughes KA: Evolution and mechanisms of long life and high fertility in queen honey bees. Age (Dordr) 2008; 30:177-185.

Ryhage R, Stenhagen E, Mass spectrometric studies. I. Saturated normal long-chain methyl esters. Arkiv Kemi 1959; 13:523-542.

Saad MA, Eid NI, Abd El-Latif HA, Sayed HM: Potential effects of yohimbine and sildenafil on erectile dysfunction in rats. Eur J Pharmacol 2013; 700:127-133.

Saeed NM, El-Demerdash E, Abdel-Rahman HM, Algandaby MM, Al-Abbasi FA, AbdelNaim AB: Anti-inflammatory activity of methyl palmitate and ethyl palmitate in different experimental rat models. Toxicol Appl Pharmacol 2012; 264:84-93.

Son DJ, Lee JW, Lee YH, Song HS, Lee CK, Hong JT: Therapeutic application of antiarthritis, pain-releasing, and anti-cancer effects of bee venom and its constituent compounds. Pharmacol Ther 2007; 115:246-270.

Song YS, Jin C, Jung KJ, Park EH: Estrogenic effects of ethanol and ether extracts of propolis. J Ethnopharmacol 2002; 82:89-95.

Suzuki KM, Isohama Y, Maruyama H, Yamada Y, Narita Y, Ohta S, Araki Y, Miyata T, Mishima S: Estrogenic activities of Fatty acids and a sterol isolated from royal jelly. Evid Based Complement Alternat Med 2008; 5:295-302.

Tam SW, Worcel M, Wyllie M: Yohimbine: a clinical review. Pharmacol Ther 2001; 91:215243. 
Thota C, Gangula PR, Dong YL, Yallampalli C: Changes in the expression of calcitonin receptor-like receptor, receptor activity-modifying protein (RAMP) 1, RAMP2, and RAMP3 in rat uterus during pregnancy, labor, and by steroid hormone treatments. Biol Reprod 2003; 69:1432-1437.

Tinwell H, Friry-Santini C, Rouquie D, Belluco S, Elies L, Pallen C, Bars R: Evaluation of the antiandrogenic effects of flutamide, DDE, and linuron in the weanling rat assay using organ weight, histopathological, and proteomic approaches. Toxicol Sci 2007; 100:54-65.

Toth N, Szabo A, Kacsala P, Heger J, Zador E: 20-Hydroxyecdysone increases fiber size in a muscle-specific fashion in rat. Phytomedicine 2008; 15:691-698.

Vitale DC, Piazza C, Melilli B, Drago F, Salomone S: Isoflavones: estrogenic activity, biological effect and bioavailability. Eur J Drug Metab Pharmacokinet 2013; 38:15-25.

Wagh VD: Propolis: a wonder bees product and its pharmacological potentials. Adv Pharmacol Sci 2013; 2013:308249. doi: 10.1155/2013/308249.

Wood CE, Appt SE, Clarkson TB, Franke AA, Lees CJ, Doerge DR, Cline JM: Effects of high-dose soy isoflavones and equol on reproductive tissues in female cynomolgus monkeys. Biol Reprod 2006; 75:477-486.

Yamazaki Y, Kiuchi M, Takeuchi H, Kubo T: Ecdysteroid biosynthesis in workers of the European honeybee Apis mellifera L. Insect Biochem Mol Biol 2011; 41:283-293.

Yücel B, Açikgöz Z, Bayraktar H, Seremet C: The effect of Apilarnil (drone bee larvae) administration on growth performance and secondary sex characteristics of male broilers. $J$ Anim Vet Adv 2011; 10:2263-2266. 


\section{Acknowledgement}

I would like to express my thanks to my supervisor, the head of the Department of Pharmacology and Biopharmacy, Róbert Gáspár Ph.D. for his guidance of my work, his support and his useful advice in the experimental work.

I am also very grateful to Prof. George Falkay, István Zupkó Ph.D. the earlier heads of the Department of Pharmacology and Biopharmacy for the possibility to take part in the Ph.D. studies.

I express my thanks to Eszter Ducza for her help in molecular pharmacology experiments and valuable advice.

My special thanks to Prof. Mária Báthori and Attila Hunyadi, Ph.D. for their help in bioactivity-guided fractionation and their encouragement.

I would like to express my great appreciation to Zoltán Béni Ph.D. and Miklós Dékány Ph.D. from Spectroscopic Research, Gedeon Richter Plc, who performed the NMR and HRMS spectroscopic investigation.

I thank all of my colleagues at the Department of Pharmacology and Biopharmacy and our cooperating partners for their assistance and advice, and also all my co-authors for contributing to my work.

Special thanks are due to Zoltánné Csiszár and Ibolya Hevérné Herke for technical assistance.

Finally I wish to thank my family for their encouragement, patience and love throughout my studies. 